Review

\title{
Exploiting the Nutrient Potential of Anaerobically Digested Sewage Sludge: A Review
}

\author{
Nicola Di Costanzo ${ }^{1, * \mathbb{D}}$, Alessandra Cesaro ${ }^{1}$, Francesco Di Capua ${ }^{2} \mathbb{D}$ and Giovanni Esposito ${ }^{1} \mathbb{C}$ \\ 1 Department of Civil, Architectural and Environmental Engineering, University of Naples Federico II, \\ Via Claudio 21, 80125 Naples, Italy; alessandra.cesaro@unina.it (A.C.); gioespos@unina.it (G.E.) \\ 2 Department of Civil, Environmental, Land, Building Engineering and Chemistry, Polytechnic University of \\ Bari, Via E. Orabona 4, 70125 Bari, Italy; francesco.dicapua@poliba.it \\ * Correspondence: nicola.dicostanzo@unina.it; Tel.: +39-3664999383
}

check for updates

Citation: Di Costanzo, N.; Cesaro, A.; Di Capua, F.; Esposito, G. Exploiting the Nutrient Potential of Anaerobically Digested Sewage Sludge: A Review. Energies 2021, 14, 8149. https://doi.org/10.3390/ en14238149

Academic Editor: Wei Liao

Received: 5 November 2021

Accepted: 2 December 2021

Published: 5 December 2021

Publisher's Note: MDPI stays neutral with regard to jurisdictional claims in published maps and institutional affiliations.

Copyright: (c) 2021 by the authors. Licensee MDPI, Basel, Switzerland. This article is an open access article distributed under the terms and conditions of the Creative Commons Attribution (CC BY) license (https:/ / creativecommons.org/licenses/by/ $4.0 /)$.

\begin{abstract}
The world is currently witnessing a rapid increase in sewage sludge (SS) production, due to the increased demand for wastewater treatment. Therefore, SS management is crucial for the economic and environmental sustainability of wastewater treatment plants. The recovery of nutrients from SS has been identified as a fundamental step to enable the transition from a linear to a circular economy, turning SS into an economic and sustainable source of materials. SS is often treated via anaerobic digestion, to pursue energy recovery via biogas generation. Anaerobically digested sewage sludge (ADS) is a valuable source of organic matter and nutrients, and significant advances have been made in recent years in methods and technologies for nutrient recovery from ADS. The purpose of this study is to provide a comprehensive overview, describing the advantages and drawbacks of the available and emerging technologies for recovery of nitrogen $(\mathrm{N})$, phosphorus $(\mathrm{P})$, and potassium (K) from ADS. This work critically reviews the established and novel technologies, which are classified by their ability to recover a specific nutrient (ammonia stripping) or to allow the simultaneous recovery of multiple elements (struvite precipitation, ion exchange, membrane technologies, and thermal treatments). This study compares the described technologies in terms of nutrient recovery efficiency, capital, and operational costs, as well as their feasibility for full-scale application, revealing the current state of the art and future perspectives on this topic.
\end{abstract}

Keywords: anaerobic digestion; circular economy; nitrogen; phosphorus; potassium; resource recovery

\section{Table of Contents}

1. Introduction

2. Anaerobically Digested Sewage Sludge: A Nutrient Source
2.1. Nitrogen
2.2. Phosphorus
2.3. Potassium

3. Technologies for the Recovery of Nutrients from ADS

3.1. Selective Nutrient Recovery: Ammonia Stripping

3.2. Multiple Nutrient Recovery

3.2.1. Struvite Precipitation

3.2.2. Ion Exchange and Adsorption

3.2.3. Membrane Technologies

3.2.3.1. Nanofiltration and Reverse Osmosis

3.2.3.2. Forward Osmosis

3.2.3.3. Membrane Distillation

3.2.3.4. Electrodialysis

3.2.4. Thermal Treatments 


\subsubsection{Incineration}

3.2.4.2. Pyrolysis and Gasification

3.2.4.3. Hydrothermal Carbonization

4. Comparative Assessment of the Strategies for Exploiting the Nutrient Potential of ADS 5. Conclusions

\section{Introduction}

In recent decades, great attention has been devoted to the recovery of nutrients from secondary resources, such as waste streams, and to their use for sustainable agriculture [1]. This interest arises from the fact that the world population is growing, resulting in an increasing demand for food. In this context, the nexus 'water-energy-food' is at the center of the challenges arising from the growth of the world population, climate change, and the depletion of natural resources. This is also reflected in the development of strategies to facilitate the transition to a circular economy, based on renewable resources. From this point of view, the increasing need for nutrient compounds for agronomic utilization makes it necessary to identify technologies able to recover nutrients, limiting the consumption of natural resources [2].

Nitrogen $(\mathrm{N})$, potassium $(\mathrm{K})$, and phosphorus $(\mathrm{P})$ have a key role in biological ecosystems [3-7]. Nitrogen is essential for the biological cycle of plants, being the main element responsible for their growth. Potassium facilitates water absorption and protects plants from parasites. Phosphorus, however, is useful for plant metabolism, by promoting a fast maturation. The first two nutrients are widely available in nature. Nitrogen is the fourth most abundant element in cellular biomass and comprises the majority of the Earth's atmosphere [8]. Before the development of the Haber-Bosch process, i.e., the industrial fixation of nitrogen gas $\left(\mathrm{N}_{2}\right)$ into ammonia $\left(\mathrm{NH}_{3}\right)$ in 1909 [9], the generation of reactive nitrogen species (e.g., $\mathrm{NH}_{3}$ ) was exclusively possible through the activity of microbes fixing the inert $\mathrm{N}_{2}$ of the atmosphere. Potassium is mainly derived from K-rich minerals mined from underground deposits, formed millions of years ago from the evaporation of sea water [10]. Phosphorus is extracted from phosphate $\left(\mathrm{PO}_{4}{ }^{3-}\right)$ rocks (phosphorites) rich in apatite (calcium phosphate minerals). The $\mathrm{PO}_{4}{ }^{3-}$ obtained from the beneficiation (i.e., the separation of phosphatic minerals) of phosphate rocks is either solubilized to produce wet-process phosphoric acid, or smelted to produce elemental phosphorus [11]. Phosphorites are the main commercial source of phosphorus, but they also represent a critical resource, being limited and geographically concentrated, and they will inevitably be exhausted in the coming centuries [12].

On the other hand, the uncontrolled discharge of high levels of nutrients into water bodies causes a serious deterioration of environmental quality, due to eutrophication. This is even more detrimental when considering that these are valuable resources that could be recovered and brought back into the material chain, in accordance with the circular economy model (Figure 1). This model addresses the scarcity of raw materials, by promoting recovery of residual flows, thereby reducing their disposal and environmental impact. The new Circular Economy Action Plan-one of the main blocks of the European Green Deal, Europe's new agenda for sustainable growth-announces initiatives to foster sustainable consumption patterns and to ensure that resources are kept in the EU economy for as long as possible. In this framework, the EU Commission will consider reviewing directives on wastewater treatment and SS and will develop an integrated nutrient management plan, in order to ensure a more sustainable application of nutrients and to stimulate the market for recovered nutrients [13]. In view of this, handling SS is going to turn into a great opportunity, although some challenges still need to be tackled.

SS is an unavoidable by-product of wastewater treatment, holding organic matter, nutrients, and often pathogens and toxic substances, such as organic contaminants and heavy metals (HMs). The management of this by-product represents a challenge, due to the high investment and operational costs related to its treatment and disposal [14]. SS is usually exploited through anaerobic digestion (AD), because it can realize sludge stabilization by 
converting a part of its organic content into biogas, which is a renewable energy source. However, AD of SS is not always practicable in small-scale wastewater treatment plants (WWTPs) or in developing countries, due to the large footprint requirement and high capital costs. In this case, dewatered SS can be collected and treated in centralized plants performing high-solid anaerobic digestion (HSAD), which can be followed by agricultural utilization of the ADS, as a strategy to reuse the nutrients contained in the SS [14].

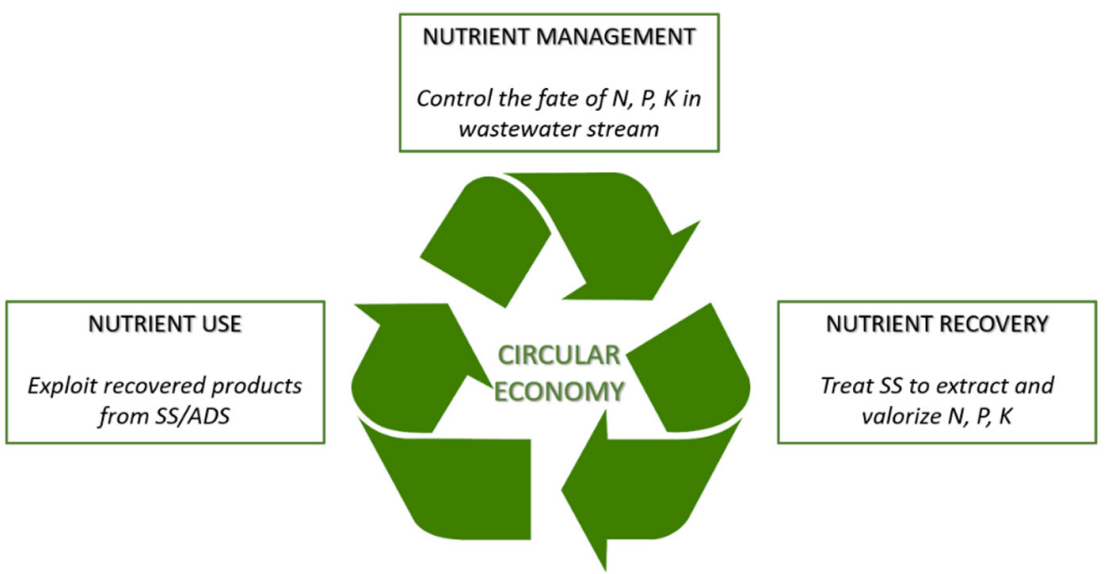

Figure 1. Sustainable management of nutrient-containing wastewater according to the circular economy model.

In the scientific literature, there are many studies that describe the current technologies applied to efficiently recover nutrients from different residual flows, including wastewater [15-17], human urine [18-20], industrial effluents [21,22], and SS [1,23-26]. Notwithstanding the great number of existing studies on the topic of nutrient recovery, only a few are available on nutrient recovery from ADS. Additionally, the latter are mainly focused on $\mathrm{N}$ and $\mathrm{P}$ recovery, whereas the fate and recovery of $\mathrm{K}$ from ADS has been poorly studied.

This review offers an overview on the current state of the art of nutrient recovery from ADS, with a focus on opportunities and challenges related to nutrient reuse coupled to HSAD of SS. Technologies for the recovery of nutrients from ADS are critically reviewed and compared, with a special attention to recent technological advances, in order to identify their state of application at industrial level, main advantages, and drawbacks, as well as to address future research directions.

\section{Anaerobically Digested Sewage Sludge: A Nutrient Source}

SS is the main residue of wastewater treatment and a major sink for the removed pollutants. It consists of a concentrated suspension of organic and inorganic solids and has a variable moisture content, depending on its origin. Conventional WWTPs generate primary and secondary SS, being different in organic and water content. Primary sludge derives from the primary sedimentation process and consists mainly of organic substances, with a content of solids in the range of $2-8 \%$, typically $4 \%$ (96\% humidity). Secondary sludge derives from secondary settling and contains mostly microbial biomass. It has a lower percentage of solids than primary sludge, with a typical value of $1 \%$ (99\% humidity). Typically, SS treatment in the sludge streamline of a WWTP pursues volume reduction via thickening and dewatering, as well as a biological stabilization via digestion processes. In small plants, due to the need for operational simplicity and limited SS flows, the digestion process is either not performed or can be performed under aerobic conditions, while in medium and large plants, AD is more commonly implemented, since the energy recovery from SS can be substantial.

AD generates a gaseous flow (the biogas) and a solid-liquid flow (the ADS). Biogas generated from AD of SS typically contains 55-65\% methane $\left(\mathrm{CH}_{4}\right), 35-44 \%$ carbon dioxide $\left(\mathrm{CO}_{2}\right)$, and small concentrations of other gases, such as hydrogen, hydrogen sulfide, carbon 
monoxide, and ammonia [6,27]. As a result, biogas can be further processed to produce biomethane and/or thermal/electrical energy for plant operation, thereby eliminating or reducing the external supply of energy. However, anaerobic digesters generally require huge operating volumes and heating energy, due to the high water content of the treated sludge, which often leads to insufficient biogas production to sustain the energy demand of the process [14,28]. Consequently, conventional AD is not always carried out in small WWTPs and highly urbanized areas with limited space [14,29]. In recent years, centralized AD plants collecting unstabilized dewatered SS from different WWTPs have been developed, with the aim of reducing the operating and capital costs for sludge treatment. These plants treat SS with a high concentration of TS $(>6 \%)$ : as a result, power consumption for heating is significantly reduced and more biogas is produced per liter of treated sludge, leading to energy-neutral or even net-energy-positive AD plants [14].

ADS is a mixture of biomass, water, and both inert and undigested solids, with potential fertilizer properties. During AD, the biological degradation of the organic matter contained in the sludge increases the concentration of soluble nutrients species, i.e., total ammonia nitrogen (TAN) and ortho-phosphate, which can be rapidly assimilated by plants for their growth [30] if the sludge is used for agricultural applications. Moreover, AD can ensure sufficient hygienization of SS, especially if performed under thermophilic conditions $\left(50-55^{\circ} \mathrm{C}\right)$ [31]. Although, pathogen reduction can also be achieved at mesophilic temperature $\left(30-35{ }^{\circ} \mathrm{C}\right)$ [32], the latter has been reported to be less effective in reducing pathogens than thermophilic $\mathrm{AD}$, due to lower operational temperatures. One of the most sustainable systems for the disposal of ADS is direct injection on agricultural land [33]. Reusing ADS as fertilizer fits the circular economy approach and has several advantages, which include the return of the organic materials and nutrients into the biocycle. Moreover, the use of ADS as a fertilizer allows reducing the demand for chemical fertilizers and, in turn, the costs for farmers.

In this context, HSAD can be considered the most direct and cost-effective pathway for the reuse of nutrients contained in SS. Indeed, HSAD generates an ADS particularly rich in nutrients and, thus, advantageous for application in agriculture [33]. Moreover, HSAD is often carried out at thermophilic temperatures, resulting in excellent hygienization of ADS, due to the higher levels of $\mathrm{pH}$ and ammonia compared to mesophilic conditions [31]. On the other hand, HSAD of SS presents certain challenges related to the high viscosity of ADS and concentration of organic compounds containing nitrogen and sulfur, which may lead to the development of inhibitors $\left(\mathrm{NH}_{3}\right.$ and $\left.\mathrm{H}_{2} \mathrm{~S}\right)$ that can slow down biological kinetics. To limit inhibition of the anaerobic process, specific treatments for ammonia and/or sulfide removal must be carried out, which can lead to the generation of agronomically valuable products, such as ammonium sulfate [33] and biogenic elemental sulfur [34]. Therefore, even though it is more challenging, thermophilic HSAD can lead to a sustainable recovery and reuse of nutrients from SS.

Nonetheless, the quality of ADS must be carefully evaluated prior to its use in agriculture, as it carries not only nutrients, but may also contain organic and inorganic pollutants [1]. According to Directive 86/278/EEC, the use of ADS in agriculture is subjected to specific restrictions regarding the $\mathrm{pH}$, homogeneity, purity, and contents of nutrients, dry matter, organic dry matter, biological (pathogenic) materials, and chemical pollutants [35]. The generation of poor-quality ADS would require proactive interventions, aimed at improving the quality of the sewage entering the WWTPs, in order to enable the direct utilization of digestate in agriculture. In the absence of remedial measures, nutrient recovery from ADS could be performed by adopting different techniques within the WWTP, in order to valorize a waste material, i.e., SS, and comply with the principles of a circular economy. It should be highlighted that nutrient recovery from ADS would be not economically profitable in the absence of incentives from national and European governments, due to the high process costs and low market value of recycled fertilizers. However, strategies for nutrient removal and recovery from ADS may be needed to avoid inhibition of the anaerobic process and/or to reduce emissions of $\mathrm{N}$ and $\mathrm{P}$ to the hydrosphere. 


\subsection{Nitrogen}

Nitrogen in ADS mainly originates from the biological degradation of proteins in the feedstock. After anaerobic hydrolysis and fermentation, approximately $70 \%$ of organic nitrogen is mineralized to ammonium nitrogen $\left(\mathrm{N}^{-\mathrm{NH}_{4}}{ }^{+}\right)$and free ammonium nitrogen (FAN or $\mathrm{N}-\mathrm{NH}_{3}$ ), which constitute the TAN of the sludge. Di Capua et al. [14] reported average total Kjeldahl nitrogen (TKN) and FAN concentrations in ADS of 52-77 g/ $\mathrm{kg}$ TS and $21-45 \mathrm{~g} / \mathrm{kg}$ TS, respectively. TAN concentrations exceeding $1500 \mathrm{mg} / \mathrm{L}$ may result in a strong inhibition of AD, even leading to process instability [36]. Thermophilic AD systems are more exposed to process instability, as the levels of FAN increase with temperature [37]. Ammonia inhibition proceeds through different mechanisms, i.e., proton imbalance, potassium deficiency, change of intracellular $\mathrm{pH}$, increase of energy requirement, and inhibition of enzymatic reactions [14]. Typically, FAN enters microbial cells by passive diffusion, resulting in abnormal cell ectoplasm, and sodium potassium exchange balance; then, FAN entering into the cell by passive diffusion can indirectly lead to a change of $\mathrm{pH}$, which affects cell stability [37]. In this way, the adoption of strategies for nitrogen recovery can be also seen as a method (if nitrogen is recovered before or during AD) of reducing the inhibitory effects of reduced nitrogen species on the anaerobic process and optimizing the process yield.

\subsection{Phosphorus}

Phosphorus is a fundamental and irreplaceable element for living organisms and has an essential role in global food production, as it is widely used by the fertilizer industry and as an additive for animal feed [38]. In 2015, according to data from the International Fertilizer Association (IFA), the total world production of phosphate rock was about 197 million tons; considering a nominal content of $\mathrm{P}_{2} \mathrm{O}_{5}$ of about $30 \%$, this corresponds to about 26 million tons of $\mathrm{P}$, with the highest production in China, Morocco, and USA [38]. The future trend of phosphorus production and consumption is currently one of the most debated issues among researchers. Based on current trends, it is estimated that the peak phosphorus production will occur by 2035 [38]. In this scenario, the need is clear for investments in innovative technologies capable of recovering phosphorus from secondary material, such as SS, wastewater, and urban and agro-industrial wastes [39]. The percentage of $\mathrm{P}$ in the dry fraction of SS can reach up to $10 \%$ in weight [40]. Based on this, SS is considered among the most abundant sources of this element among organic wastes [41]. The amount of phosphorus in SS depends on the type of wastewater treatment, since the phosphorus contained in wastewater has to be sequestrated into a solid to be removed. Conventional phosphorus removal works by fixing the phosphorus into the sludge in one of two ways: chemically or biologically. Chemical processes are based on the use of coagulants that hydrolyze rapidly and form multicharged polynuclear complexes with enhanced adsorption characteristics; once suspended particles have flocculated into larger particles, they can be removed from the treated water by sedimentation [3]. Typically, precipitation of soluble phosphorus occurs with aluminum or iron salts, which convert it into insoluble $P$ compounds [42]. Although easy to implement, chemical precipitation increases the cost of sewage treatment and the volume of sludge to be managed [43]. Biological processes exploit the ability of phosphorus accumulating organisms (PAO) to accumulate $\mathrm{P}_{-} \mathrm{PO}_{4}{ }^{3-}$ as polyphosphates in amounts exceeding their metabolic need [42]. The most widely used technology for biological treatment is conducting alternating aerobic and anaerobic processes, enabling the combined removal of carbon, nitrogen, and phosphorus. The first step is to carry out the anaerobic process, during which PAO hydrolyze polyphosphates and release phosphorus from cells in the form of ortho-phosphates, to gain energy for the uptake of organic carbon, which is absorbed as simple organic compounds (e.g., volatile fatty acids) and stored within the cell as polyhydroxyalkanoates (PHA). Next, the activated sludge goes into an aerated basin, where PAO begin to uptake ortho-phosphates to be

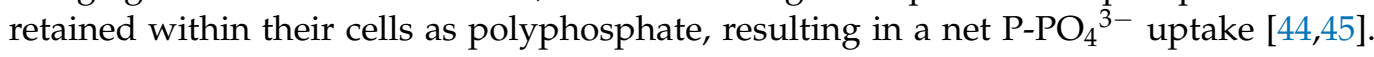
The phosphorus sequestrated into bacterial cells ends up in the sludge streamline of the 
WWTP and eventually enters AD. Here, $\mathrm{P}$ is partly retained in solids and partly released in the liquid phase, due to PAO activity under anaerobic conditions and VS degradation. As a result, both liquid and solid fraction of ADS can be considered valuable sources of phosphorus.

\subsection{Potassium}

Similarly to nitrogen and phosphorus, potassium is one of the essential microminerals for plant survival. Potassium is of great importance for soil health, plant growth, and animal nutrition. Its primary function in plants consists in maintaining osmotic pressure and cell size, thus influencing photosynthesis and energy production [10]. Most potassium is found in the earth's crust in the form of minerals, such as orthoclase (potassium feldspar, a common rock-forming mineral), sylvite $(\mathrm{KCl})$, carnallite $\left(\mathrm{KCl} \cdot \mathrm{MgCl}_{2} \cdot 6 \mathrm{H}_{2} \mathrm{O}\right)$, kainite $\left(\mathrm{MgSO}_{4} \cdot \mathrm{KCl} \cdot 3 \mathrm{H}_{2} \mathrm{O}\right)$, and langbeinite $\left(\mathrm{MgSO}_{4} \cdot \mathrm{K}_{2} \mathrm{SO}_{4}\right)$. In 1980, the main mining area used for potassium salt extraction was in Germany, while today most of the potassium minerals (especially sylvite and carnallite) come from Canada, the United States, and Chile. The world production of extracted potassium is about 50 million tons, and the reserves are estimated to be over 10 billion tons [46]. Potassium-based fertilizer prices have increased by as much as four times during the last decade and there are issues around supply of K-based fertilizers to developing nations, due to the limited global distribution of potash ores (the main source of K) [3]. Potassium concentrations in SS and ADS range between $0.3 \%$ and $0.7 \%$ of $\mathrm{K}$ per weight of dry solids [14,25,47]. As indicated, the potassium content in the ADS is low, which is why potassium is typically recovered through technologies also applied for phosphorus and nitrogen recovery, in particular through K-struvite precipitation, membrane technologies, and thermal treatments.

\section{Technologies for the Recovery of Nutrients from ADS}

This section aims to give an overview of the different possible methods for recovering nitrogen, phosphorus, and potassium from ADS. These technologies can either target a specific nutrient (e.g., ammonia stripping) or allow the simultaneous recovery of multiple elements (e.g., struvite precipitation for $\mathrm{P}_{-} \mathrm{PO}_{4}{ }^{3-}$ and $\mathrm{N}-\mathrm{NH}_{4}{ }^{+}$or potassium recovery). Typically, nutrient recovery technologies are applied directly to the ADS (or SS) stream or to a ADS liquid fraction (e.g., centrate).

\subsection{Selective Nutrient Recovery: Ammonia Stripping}

This process removes part of the TAN contained in the sludge by shifting the $\mathrm{NH}_{4}{ }^{+} / \mathrm{NH}_{3}$ equilibrium towards FAN, which is removed from the system by a gas stream. Ammonia stripping is conventionally executed in heated packed column reactors on the liquid fraction achieved from sludge dewatering [14]; the air blown in the column from the bottom (stripping gas), traveling along the surface of the contact material, carries the ammonia. The stripped ammonia is transported to an absorption unit, where it is absorbed into sulfuric (or nitric) acid solutions, resulting in the production of ammonium sulfate (or nitrate), a marketable platform chemical for the production of base fertilizers and other chemical products [47]. Recently, approaches based on $\mathrm{NH}_{3}$ stripping from ADS and the liquid fraction of ADS have been established and extended from lab-scale to full-scale around the world [48].

Ammonia stripping is established based on the change of physical conditions of the sludge, enabling the transition of $\mathrm{NH}_{4}{ }^{+}$to $\mathrm{NH}_{3}$, which must be efficiently removed from the liquid phase [49]. Increasing temperature and $\mathrm{pH}$ shifts the $\mathrm{NH}_{4}{ }^{+} / \mathrm{NH}_{3}$ equilibrium towards FAN. It was shown that increasing the $\mathrm{pH}$ (up to 10), temperature, and flow rate of the stripping gas can significantly improve the amount of stripped nitrogen [50]. Nevertheless, effective ammonia stripping during AD of SS can be obtained without using alkaline reagents for $\mathrm{pH}$ increase, as the concomitant stripping of $\mathrm{CO}_{2}$ helps increase the $\mathrm{pH}$ of the system and shift the $\mathrm{NH}_{4}{ }^{+} / \mathrm{NH}_{3}$ equilibrium towards FAN [51]. 
The ammonia stripping process is strongly conditioned by the type of matrix being treated; the passage in the stripping column is suitable for low viscous fluids, such as wastewater and the liquid fraction of municipal SS. For high-viscosity fluids, however, reactors with packed materials are not suitable, as they would result in rapid clogging. Therefore, TS content plays a key role in choosing the most suitable technology for ammonia stripping, as if affects the rheological characteristics of the medium [52]. To overcome this issue, it is necessary to develop new technologies specifically suited to ADS, especially if it comes from HSAD. Due to the higher TS concentration compared to conventional AD, the operation of packed columns for direct ammonia removal from ADS is impossible. Moreover, the high TS concentration in HSAD results in much higher TAN and FAN levels inside the digester, which may inhibit the biological process. Therefore, TAN removal cannot be performed as a post-treatment only on the liquid fraction of ADS but should be foreseen as a side-stream process of HSAD.

Side-stream ammonia stripping represents a strategy for reducing ammonia toxicity during AD. The HSAD of SS produces TAN levels as high as $4 \mathrm{~g} / \mathrm{L}$, due to the high concentrations of proteinaceous organic materials in the feedstock [53]. High ammonia concentrations may be responsible of inhibitory effects on $\mathrm{AD}$, hindering and slowing down the digestion process. The ammonia toxicity is amplified when the process is conducted at thermophilic temperatures [14]. To solve the problem of ammonia inhibition, numerous techniques, including dilution, co-digestion, and side-stream ammonia stripping, could be applied. The latter approach seems to be the most promising. During AD, a portion of the digested sludge is continually removed and treated in a stripping unit, where the ammonia produced from the digestion process is transferred to a gas phase (commonly biogas or air) and then put into contact with a sulfuric acid solution, to produce ammonium sulfate. This process prevents the inhibition of the anaerobic process and simultaneously recovers ammonia as ammonium sulfate, which can be used as fertilizer. Costamagna et al. [54,55] proposed a thin film evaporator (TFE) as a suitable technology for the continuous side-stream stripping of ammonia from dewatered SS (12.5\% TS) during thermophilic HSAD. As an alternative to conventional packed columns when treating dewatered SS, this technology does not require solid/liquid separation and avoids clogging issues [14]. With this technology, the ADS is continuously recirculated to the TFE column, which is thermally insulated and allows the contact between the ADS film (5-15 $\mathrm{mm}$ ) and the uprising biogas flow, which is enriched in ammonia. The treated sludge is then recirculated to the digester and the ammonia-rich biogas collected from the TFE is fed to an absorption column to remove ammonia and producing ammonium sulfate. During the trial period, Costamagna et al. [55] could recover $4.1 \mathrm{~g} \mathrm{~N}-\mathrm{NH}_{4}{ }^{+}$per $\mathrm{kg}$ of sludge fed to the digester, i.e., $19.3 \mathrm{~g} \mathrm{~N}-\mathrm{NH}_{4}{ }^{+}$per $\mathrm{kg}$ TS fed to the digester, as ammonium sulfate. Side-stream ammonia stripping during HSAD couples process non-inhibition with the possibility of recycling nutrients from SS using a two-fold production of fertilizer, i.e., ammonium sulfate and high-solid ADS. Recently, Di Capua et al. [51] proposed the use of air as a stripping gas in the TFE during the HSAD of SS (TS 11.04\% and VS 7.01\%). In this process, ADS is continuously recirculated from the digester to the TFE, where ammonia is stripped by an air stream. The TFE performance was monitored for 140 days, by gradually increasing the specific airflow rate from 1.5 to $4.6 \mathrm{~m}^{3}$ air $/ \mathrm{kg}$ ADS. The authors demonstrated that ammonia removal from SS was primarily influenced by the airflow rate, as the removal efficiency increased from $17.1 \%$ to $33.3 \%$ when the flow rate was increased from 1.5 to $4.6 \mathrm{~m}^{3}$ air $/ \mathrm{kg}$ ADS. In contrast, changes in temperature (from $63.6{ }^{\circ} \mathrm{C}$ to $73.6{ }^{\circ} \mathrm{C}$ ) and $\mathrm{CO}_{2}$ concentration (between $5 \%$ and $17 \%$ ) did not influence the ammonia stripping significantly. Use of air as a stripping gas did not exert any inhibitory impact on methane production, even when $4.6 \mathrm{~m}^{3}$ air were fed per $\mathrm{kg}$ of ADS, which was attributed to low residence time of $2.5 \mathrm{~min}$ in the TFE and small fraction of ADS (only 1.7\% of the total digestion volume) fed daily to the TFE. The process allowed avoiding inhibition of the HSAD process and, at the same time, producing nutrient-rich ADS and ammonium sulfate, to be applied as fertilizers. 
Ammonia stripping from SS has been carried out before or after AD. In the former case, it serves as a pretreatment and has the advantage of improving the AD process, limiting the problems related to ammonia inhibition in $\mathrm{AD}[56,57]$. In the latter case (Table 1), the ammonia nitrogen produced from the digestion process can be recovered as ammonium sulfate/nitrate, since the air leaving the stripping tower, enriched in the ammonia transferred to the gaseous phase, can be treated in a scrubber with sulfuric/nitric acid to obtain ammonium sulfate/nitrate.

Table 1. Removal and recovery of $\mathrm{N}^{-\mathrm{NH}_{4}}{ }^{+}$from ADS streams through ammonia stripping.

\begin{tabular}{|c|c|c|c|c|c|c|}
\hline Sludge Type & $\begin{array}{l}\text { Type of Ammonia } \\
\text { Stripping }\end{array}$ & $\begin{array}{l}\text { TS } \\
(\%)\end{array}$ & $\begin{array}{l}\text { Influent TAN } \\
\qquad(\mathrm{g} / \mathrm{L})\end{array}$ & $\begin{array}{c}\mathrm{T} \\
\left({ }^{\circ} \mathrm{C}\right)\end{array}$ & $\begin{array}{c}\mathrm{N}-\mathrm{NH}_{4}{ }^{+} \\
\text {Removal (\%) }\end{array}$ & Ref. \\
\hline \multirow{4}{*}{$\begin{array}{c}\text { Digestates taken from an anaerobic } \\
\text { digester }\end{array}$} & Down-stream & - & 4.98 & 70 & $17-86$ & \multirow{4}{*}{ [58] } \\
\hline & In situ & - & $6-6.3$ & 35 & $58-90$ & \\
\hline & Side-stream & - & 3.98 & 70 & $34-84$ & \\
\hline & Up-stream & - & $6-6.25$ & 70 & $44-88$ & \\
\hline Anaerobic digestion effluent & Up-stream & $2^{1}$ & 1.544 & 15 & $72.1-95.3$ & [56] \\
\hline ADS & $\begin{array}{l}\text { Side-stream } \\
\text { with TFE }\end{array}$ & 10.7 & 3.65 & 65 & 21.2 & [54] \\
\hline High-solid anaerobic digestion of SS & $\begin{array}{l}\text { Side-stream } \\
\text { with TFE }\end{array}$ & 11.04 & 3.714 & $63.6-73.6$ & $17.1-33.3$ & [51] \\
\hline
\end{tabular}

${ }^{1}$ Total suspended solids.

\subsection{Multiple Nutrient Recovery}

\subsubsection{Struvite Precipitation}

Struvite is a crystalline mineral composed of equimolar concentrations of $\mathrm{Mg}^{2+}, \mathrm{NH}_{4}{ }^{+}$ and $\mathrm{PO}_{4}{ }^{3-}$, with the chemical formula $\mathrm{MgNH}_{4} \mathrm{PO}_{4} \cdot 6 \mathrm{H}_{2} \mathrm{O}$. Struvite consists of $\mathrm{PO}_{4}{ }^{3-}$ (tetrahedral), $\mathrm{Mg}\left(6 \mathrm{H}_{2} \mathrm{O}\right)^{2+}$ (octahedral), and $\mathrm{NH}_{4}{ }^{+}$(tetrahedral) groups, which are held together by hydrogen bonds [59]. The formation of struvite is controlled by two mechanisms: nucleation (the initial formation of the crystal) and crystal growth. This last phase is characterized by a mass transfer through the diffusive layer surrounding the crystal and by the capture of the solute inside the crystal. In most of the published works on the principles of struvite formation, it has been highlighted that supersaturation ratio and $\mathrm{pH}$ have been found to be the most influential parameters on the crystallization mechanism [42]. The crystal formation process is also strongly influenced by other parameters, such as the presence of other ionic species (e.g., $\mathrm{Ca}^{2+}, \mathrm{Na}^{+}, \mathrm{K}^{+}$) that can interfere with crystal formation, replacing $\mathrm{N}^{-\mathrm{NH}_{4}}{ }^{+}$(e.g., $\mathrm{K}^{+}$) or $\mathrm{Mg}^{2+}$ (e.g., $\mathrm{Ca}^{2+}$ ) and leading to the formation of a mineral similar to struvite but different in composition. When $\mathrm{K}^{+}$replaces $\mathrm{N}-\mathrm{NH}_{4}{ }^{+}$, potassium struvite precipitation $\left(\mathrm{KMgPO}_{4} \cdot 6 \mathrm{H}_{2} \mathrm{O}\right)$ can occur [60]. This precipitate is also known as K-struvite, an isomorphous analogue of struvite that can also be used as slow-release fertilizer [61]. The physical and chemical properties of K-struvite are similar to those of typical struvite crystals (e.g., the needle-like shape and transparent to whitish appearance [62]), although the density of K-struvite $\left(1.864 \mathrm{~g} / \mathrm{cm}^{3}\right)$ is slightly higher than that of struvite $\left(1.711 \mathrm{~g} / \mathrm{cm}^{3}\right)$ [63]. A suitable $\mathrm{pH}$ range for K-struvite precipitation is between 9.0 and 11.0, which is moderately higher than the $\mathrm{pH}$ range for struvite formation (8.5-9.5) [64].

Struvite precipitation depends on several parameters, perhaps most notably $\mathrm{pH}$ and the molar ratio of $\mathrm{NH}_{4}{ }^{+}, \mathrm{PO}_{4}{ }^{3-}$, and $\mathrm{Mg}^{2+}$ in the liquid phase [65]. Several researchers investigated the $\mathrm{pH}$ of minimum solubility for struvite [66], reporting values ranging from 7.8 [67] to 10.3 [68]. Generally, struvite precipitation occurs when $\mathrm{NH}_{4}^{+}, \mathrm{Mg}^{2+}$, and $\mathrm{PO}_{4}{ }^{3-}$ concentrations overcome the solubility product $\left(\mathrm{K}_{\mathrm{sp}}\right)$ of struvite under alkaline conditions [69]. In the literature, different $K_{\mathrm{sp}}$ values are reported, ranging from $2.50 \cdot 10^{-13}$ to $7.50 \cdot 10^{-14}$ [66]. Struvite precipitation occurs spontaneously in many WWTPs, resulting in scale deposits that are a significant concern for plant operation. As a result, struvite 
formation is perceived as a nuisance, affecting the efficiency of treatment processes and causing maintenance problems. However, for intentional struvite precipitation, most of the potential struvite sources need an input of chemicals for a $\mathrm{pH}$ increase and/or for the adjustment of $\mathrm{Mg}, \mathrm{NH}_{4}{ }^{+}$, and $\mathrm{PO}_{4}{ }^{3-}$ concentrations, to reach an optimal molar ratio $\left(\mathrm{Mg}^{2+}: \mathrm{PO}_{4}{ }^{3-}: \mathrm{NH}_{4}{ }^{+}\right)$. This must be assessed case-by-case, as it strongly depends on the chemical-physical characteristics of wastewater [70]. Uysal et al. [71] observed that the optimal Mg: $\mathrm{PO}_{4}{ }^{3-}: \mathrm{NH}_{4}{ }^{+}$molar ratio for struvite precipitation from SS was near to the equimolar ratio, being 1.5:1:1 at a $\mathrm{pH}$ of about 9.0. A supply of $\mathrm{Mg}^{2+}$ is generally required to make struvite precipitation effective, due to the lack of adequate $\mathrm{Mg}$ concentrations in the majority of potential struvite sources, including SS [72].

Table 2 shows data present in the literature regarding nutrient removal and recovery from ADS through struvite precipitation, in relation to the parameters described above. Munir et al. [73] showed an increase in phosphate recovery, due to an increase of $\mathrm{pH}$, i.e., $7.1 \mathrm{mg} / \mathrm{L}$ at $\mathrm{pH} 8$ compared to $10.5 \mathrm{mg} / \mathrm{L}$ at $\mathrm{pH}$ 9. This result was also confirmed by Marti et al. [74], where the $\mathrm{PO}_{4}{ }^{3-}$ recovery was $152 \mathrm{mg} / \mathrm{L}$ at $\mathrm{pH} 7$ compared to $164 \mathrm{mg} / \mathrm{L}$ at $\mathrm{pH}$ 8. Uysal et al. [71] and Zheng et al. [75] observed that as the ratio Mg:N:P changes, the nutrient removal/recovery efficiency varies as well, with the best results obtained for a molar ratio of 1.3:1:1.

Table 2. Recovery of N, P, and K from ADS streams through struvite precipitation.

\begin{tabular}{|c|c|c|c|c|c|c|c|}
\hline Sludge Type & $\begin{array}{c}\text { TS } \\
(\mathrm{g} / \mathrm{L})\end{array}$ & $\mathrm{pH}$ & Mg:N:P & $\begin{array}{c}\text { P Recovery } \\
(\%)\end{array}$ & $\begin{array}{c}\text { N Recovery } \\
(\%)\end{array}$ & $\begin{array}{c}\text { K Recovery } \\
(\%)\end{array}$ & Ref. \\
\hline \multirow{5}{*}{ ADS } & \multirow{5}{*}{-} & 8 & 1:1:1 & $<0^{1}$ & 85.42 & - & \multirow{5}{*}{ [70] } \\
\hline & & 8.5 & $1: 1: 1$ & $<0^{1}$ & 89.16 & - & \\
\hline & & 9 & $1: 1: 1$ & 47.1 & 88.79 & 22.2 & \\
\hline & & 9 & 1.3:1:1 & 92.5 & 89.35 & 32.5 & \\
\hline & & 9 & $1.5: 1: 1$ & 95.0 & 89.35 & 24.7 & \\
\hline ADS & $37.26 \pm 8.4$ & $6.8-7.2$ & 1:1.7:1.2 & 58 & - & - & [73] \\
\hline Acidified ADS & - & 9.6 & 1-1.4:1:0.8-1.2 & 96-100 & $75-90$ & - & [74] \\
\hline ADS supernatant & 1.309 & 10 & $1-3: 1-7.871: 1-2$ & $20.9-99.6$ & 29 & - & {$[75]$} \\
\hline ADS centrate & - & 7.67 & $1-2: 1: 0.8-1$ & 95.9-99.8 & $76.7-99.5$ & - & [76] \\
\hline Liquid fraction of ADS & $16-29.6$ & $6.2-8.7$ & 1-1.5:6.7-7.9:1 & $\begin{array}{c}76.0-83.9 \\
(35.4-72.6 \\
\text { as struvite) }\end{array}$ & - & - & [77] \\
\hline ADS & 29.3 & 9.5 & $1-1.2: 1: 1-1.2$ & $81-86.7$ & $92.6-96$ & - & [78] \\
\hline
\end{tabular}

Struvite is considered a valid fertilizing product, because it contains nutrients such as nitrogen and phosphorus (essential for plant growth) [79], and its low solubility induces a slow release of nutrients in the soil, which allows optimal plant growth and avoids potentially harmful overdose phenomena [2]. As a result, the crystallization of struvite has gained interest for phosphorus recovery [42] and to remove $\mathrm{NH}_{4}{ }^{+}$[80] from waste streams, such as wastewaters and SS. Interestingly, struvite precipitation in HSAD digesters treating dewatered SS may have a double positive effect: (1) avoiding process inhibition, due to TAN removal, and (2) increasing the fertilizing potential of the produced ADS [14]. The occurrence and quantification of struvite precipitation during the HSAD of SS and the struvite content of the produced ADS should be investigated in future studies.

\subsubsection{Ion Exchange and Adsorption}

Ion exchange and adsorption are similar physical-chemical processes as they both utilize sorbents in a column bed to extract the target compounds from the feed solution. Adsorption is a mass transfer phenomenon, by which one or more constituents present in the liquid phase are fixed on a porous solid surface. Contrarily to ion-exchange, which 
is driven by ionic forces, adsorption occurs due to weak intermolecular forces, i.e., Van der Waals forces, and, thus, the process is considered reversible. In ion exchange, mobile ions of a solid matrix (adsorbent) are exchanged with ions having a similar electric charge present in the solution (adsorbate). Electrostatic forces allow the bonding between the ions of the adsorbate and the charges present on the surface of the adsorbent. Ion exchange and adsorption may occur simultaneously in one media, such as zeolites, clays, and resins, whether or not chemically or thermally modified [48]. After a certain period, the sorbent reaches its capacity and must be regenerated. Regeneration can be achieved with various techniques, including washing with nitric acid $\left(\mathrm{HNO}_{3}\right)$ or sodium chloride $(\mathrm{NaCl})$ [81]. Ion exchange through natural minerals (e.g., zeolites or bentonites) has gained importance because of its low cost and ease of use. Furthermore, ion exchange enables the recovery of $\mathrm{N}-\mathrm{NH}_{4}{ }^{+}$and its reuse for fertilizing purposes $[82,83]$. For example, the ammonium-zeolite complex can applied directly to soil as it is decomposed slowly by soil bacteria and released to the soil as a nutrient [84]. The high ion exchange capacity, large reserves, shortage of competing minerals, and relatively low market price make zeolite an attractive mineral for application at large scale [85]. Despite this, there are no applications at full-scale, but only at lab-scale, due to the rapid obstruction of the adsorbent bed (which makes zeolite treatment potentially feasible only for the liquid fraction of ADS), as well as the necessary maintenance of the capacity of the bed after multiple recovery/regeneration cycles, which can increase the operating costs. Zeolite minerals differ in silicon (Si) and aluminum (Al) contents. Zeolite minerals differ in silicon ( $\mathrm{Si}$ ) and aluminum (Al) contents; among natural zeolites, clinoptilolite (Si:Al ratio equal to 5.7) is usually used for ion exchange, due to its high sorption and ion-exchange capacity and selectivity [86]. Zeolites exert their ammonia removal action through two different mechanisms: (1) ion exchange for $\mathrm{N}^{-\mathrm{NH}_{4}}{ }^{+}$, and (2) adsorption of $\mathrm{N}^{-\mathrm{NH}_{3}}$ [87]. Temperature and $\mathrm{pH}$ strongly influence the removal efficiency of ammonia: the higher the temperature, the higher the removal efficiency achieved; regarding $\mathrm{pH}$, the removal efficiency is approximately constant between values of 4 and 8 , and rapidly decreases outside this range [80]. Zeolites are used for both $\mathrm{N}_{-} \mathrm{NH}_{4}{ }^{+}$and P- $\mathrm{PO}_{4}{ }^{3-}$ removal [88]; $\mathrm{P}-\mathrm{PO}_{4}{ }^{3-}$ can be adsorbed by zeolite, although the removal efficiency has been reported to be much lower than that of $\mathrm{N}^{-\mathrm{NH}_{4}}{ }^{+}$[89]. This is due to the fact that zeolite, or rather, clinoptilolite has a higher selectivity for monovalent ions such as ${\mathrm{N}-\mathrm{NH}_{4}}^{+}$ and $\mathrm{K}^{+}[85,90-92]$. The best results in terms of removal/recovery of $\mathrm{N}^{-\mathrm{NH}_{4}}{ }^{+}$were obtained with the use of mesolite [93] and polymeric resins [92], of $95 \%$ and $98 \%$, respectively. Kocatürk-Schumacher et al. [94], using clinoptilolite, demonstrated that $\mathrm{N}^{-\mathrm{NH}_{4}}{ }^{+}$and $\mathrm{K}^{+}$ can be removed from the liquid fraction of digestate with high removal efficiencies, i.e., $86 \%$ and $78 \%$, respectively. These authors also showed that preconditioning of clinoptilolite with sodium ions had no significant effect on the removal of $\mathrm{NH}_{4}{ }^{+}$and $\mathrm{K}^{+}$and that increasing the initial loading ratio significantly increased the nutrient concentrations of clinoptilolite but decreased the nutrient removal efficiencies from the liquid fraction of the digestate. This result was also confirmed by Gong et al. [95], who observed that an increased initial load leads to a higher concentration of nutrients in the polymer resins, but results in a low removal efficiency (37\%). The costs of ion exchange and adsorption depend on several factors, including the availability of the sorption material used, the applied recovery/regeneration method, and the regeneration frequency of the adsorption medium. To date, no cost-benefit analyses for nutrient recovery from ADS using zeolites or other sorbents have been reported in the literature [81].

\subsubsection{Membrane Technologies}

Membrane filtration is generally applied to the liquid fraction of the ADS, which is forced through a membrane by means of pressure [96]. With a driven pressure applied, porous membranes can retain larger particles, while allowing smaller ones to pass through [48]. Membrane systems can be operated either with a constant permeate flux (flow rate per unit of membrane area, $\mathrm{L} / \mathrm{m}^{2} \mathrm{~h}$ ) and variable transmembrane pressure (TMP) or with a constant TMP and variable permeate flux [97]. Membrane technology 
has evolved considerably in recent years and it can be applied in almost all industrial sectors [98], including nutrient recovery from waste streams such as SS and ADS (Table 3). Gerardo et al. [99] used membrane filtration coupled with acid treatment and dialysis techniques and showed that $271.11 \mathrm{mg} / \mathrm{L} \mathrm{N}-\mathrm{NH}_{3}$ and $25.60 \mathrm{mg} / \mathrm{L} \mathrm{P}_{-}-\mathrm{PO}_{4}{ }^{3-}$ could be recovered from filtered ADS supernatant with initial concentrations of $686.2 \mathrm{mg} / \mathrm{L} \mathrm{N}-\mathrm{NH}_{3}$ and $41.51 \mathrm{mg} / \mathrm{L} \mathrm{P}_{-} \mathrm{PO}_{4}{ }^{3-}$. Membrane filtration effectively separates the ADS stream into a fraction rich in solids (retentate or concentrate) and an aqueous solution that passes through the membrane (permeate). Based on the operating TMP, membranes can be categorized as low-pressure membranes (LPMs) and high-pressure membranes (HPMs). LPMs include microfiltration (MF) and loose ultrafiltration (UF) membranes, typically operated at TMPs below $200 \mathrm{kPa}$. Meanwhile, HPMs such as tight UF, nanofiltration (NF), and reverse osmosis (RO) membranes are operated at TMPs above $200 \mathrm{kPa}$ [97]. MF and UF are mainly applied for the removal of suspended solids, microorganisms, and macro-molecules, while $\mathrm{NF}$ and $\mathrm{RO}$ are used for the removal of smaller organics and ions, including $\mathrm{NH}_{4}{ }^{+}, \mathrm{PO}_{4}{ }^{3-}$, and $\mathrm{K}^{+}[100,101]$. The main drawbacks of membrane processes is fouling, which leads to a rapid decline of the permeate flux over time; to maintain their separation performance, membranes must be cleaned and replaced periodically [97]. Recently, of the different membrane technologies, there are three processes: forward osmosis (FO), membrane distillation (MD), and electrodialysis (ED), showing promising results for nutrient recovery. Their selectivity is conducive to the formation of valuable nutrients, and their energy requirements and related costs are competitive with common pressure-driven membrane processes.

\subsubsection{Nanofiltration and Reverse Osmosis}

NF and RO have been widely applied, from laboratory to full scale, for potable water reclamation from wastewater and the removal of contaminants such as HMs and emerging organics [102-104]. In terms of nutrient removal and recovery from SS streams, NF and $\mathrm{RO}$ have been applied with the objective of recovering $\mathrm{P}$ by concentration in the retentate stream and precipitation with $\mathrm{Ca}$ ions. This process requires the use of acid-resistant and durable membranes, as cleaning with strong acids is periodically required to remove the Ca-P crystals attached to the membranes. Nitric acid is regarded as the best option, as it generates a solution rich in $\mathrm{N}$ and $\mathrm{P}$, which can be locally applied as a fertilizer. Nir et al. [105] proposed a two stage NF/RO system for the simultaneous removal and recovery of $P$ from WWTP secondary effluents, which could also be applied to the liquid fraction of ADS. In the first stage, a NF/RO treatment allows obtaining a permeate with high recovery ratio (i.e., ratio of permeate to influent flow). The obtained concentrate is sent to a second NF stage, where P and Ca ions exceed the supersaturation levels. Proper $\mathrm{P}$ precipitation is achieved in a crystallizer by adjusting the $\mathrm{pH}$ to reduce the formation of $\mathrm{CaCO}_{3}$ crystals, which may reduce the weight fraction of $\mathrm{P}$ in the precipitate. At a $95 \%$ recovery ratio, $\mathrm{P}$ recovery in the retentate could reach $>90 \%$. The costs of the proposed scheme, including membrane replacement and acid addition for $\mathrm{pH}$ adjustments, were estimated to be around 0.05 USD per $\mathrm{m}^{3}$ of influent wastewater, being competitive with the conventional $\mathrm{P}$ removal and recovery method based on chemical $\mathrm{P}$ precipitation through addition of $\mathrm{Al} / \mathrm{Fe}$ salts.

\subsubsection{Forward Osmosis}

FO is carried out by placing a semipermeable membrane between two solutions with different solute concentrations: a concentrated draw solution, and a more diluted feed solution. Instead of hydraulic pressure, FO employs an osmotic pressure difference [106]. For this reason, unlike other membrane processes with a hydraulic pressure requirement, such as NF (3-20 bar) and RO (5-120 bar), FO has the advantage of low energy consumption. Moreover, FO has demonstrated a lower fouling propensity and higher fouling reversibility compared to pressure-driven RO [107-109].

The application of FO is promising, due to its distinctive advantages but, up to now, FO has only been assessed in laboratory-scale studies, and pilot and full-scale validations 
should be conducted. Nguyen et al. [109] evaluated the feasibility of applying FO on municipal wastewater sludge, showing recovery efficiencies of around $96 \%$ of $\mathrm{N}^{-\mathrm{NH}_{4}}{ }^{+}$and $98 \%$ of $\mathrm{P}-\mathrm{PO}_{4}{ }^{3-}$. Soler-Cabezas et al. [110] studied the recovery of nutrients in ADS centrate by FO using two industrial effluents as draw solutions; the results showed that $\mathrm{NH}_{4}{ }^{+}$and $\mathrm{K}^{+}$could be concentrated with a factor (ratio between final and initial concentrations in ADS centrate) of 1.2 and 1.08, respectively. Conversely, phosphorous cannot be concentrated because of its spontaneous precipitation as calcium phosphate during FO.

\subsubsection{Membrane Distillation}

Membrane distillation (MD) utilizes low-grade heat to drive separation [111]. In this process, the feed stream is separated from the distillate by a hydrophobic and microporous membrane, which cannot be penetrated by the liquid. The transport mechanism through the membrane occurs only in the vapor phase, and it is driven by a difference in the partial vapor pressure; consequently, MD can offer complete rejection of all non-volatile constituents in the feed solution [106,112]. From this point of view, MD can be used for the recovery of valuable components, concentrating them either in the feed or in the permeate. For example, non-volatile inorganic nutrient ions, such as $\mathrm{K}^{+}$and $\mathrm{PO}_{4}{ }^{3-}$, can be concentrated in the feed stream to make the following nutrient precipitation easier [84], while $\mathrm{NH}_{3}$, being more volatile, can be transported through the hydrophobic membrane pores along with the vapor. Xie et al. [106] reported that over $96 \%$ of the ammonia could be recovered from the ADS centrate in the form of an aqueous solution, which could then be reused as fertilizer. To further enhance the capture of ammonia vapor in contact with MD, a low concentration of sulfuric acid $\left(\mathrm{H}_{2} \mathrm{SO}_{4} 0.1 \mathrm{M}\right)$ was used on the permeate side; in this way, ammonia recovery was improved up to $99 \%$, with ammonium sulfate produced as a fertilizer. Kim et al. [113] applied a MD process, on laboratory scale, to treat the supernatant of ADS produced from the treatment of livestock wastewater. The authors, performing a short-term distillation for $90 \mathrm{~min}$ with a feed solution $\left(\mathrm{pH} \mathrm{8.5)}\right.$ at $60^{\circ} \mathrm{C}$ and permeate stream at $20{ }^{\circ} \mathrm{C}$, achieved a more than $99 \%$ rejection of phosphorus and $90.3 \%$ rejection of TN. Xie et al. [114] demonstrated the extraction of phosphorus from ADS centrate by a hybrid $\mathrm{FO}-\mathrm{MD}$ system with a $\mathrm{MgCl}_{2}$ draw solution. In this $\mathrm{FO}-\mathrm{MD}$ hybrid process, FO concentrates $\mathrm{P}_{-} \mathrm{PO}_{4}{ }^{3-}$ and $\mathrm{N}-\mathrm{NH}_{4}{ }^{+}$for the following nutrient recovery in the form of struvite, while MD is used to recover the draw solution. The reverse $\mathrm{Mg}^{2+}$ permeation (reverse $\mathrm{Mg}^{2+}$ flux of $12 \mathrm{mmol} / \mathrm{m}^{2} \mathrm{~h}$ ) was also important, which substantially increased the feed $\mathrm{Mg}^{2+}$ concentration in the system, thereby supplementing $\mathrm{Mg}^{2+}$ for struvite formation. Struvite formation was not quantified but was indicated by the continuous decrease of solution $\mathrm{pH}$ and by the ionic product that was $10^{-5.77} \mathrm{M}^{3}$, above the struvite conditional solubility product. To prove this, the precipitates obtained in the hybrid process were verified to be struvite crystals by examining the crystal morphology, element composition, and crystal structure.

\subsubsection{Electrodialysis}

Electrodialysis (ED) is a membrane process in which semi-permeable membranes are applied to separate ions under the influence of an electric potential that allows cations and anions to migrate towards the cathode and the anode, respectively. ED can selectively fraction nutrients from wastewater streams into high-quality nutrient products [106]. Ion separation is achieved by ion-exchange membranes, which comprise cation-selective, anionselective, and bipolar membranes (which comprise a cation-selective and an anion-selective membrane). When bipolar membranes are used in an ED process, dissociation of solvent molecules, such as water, into $\mathrm{H}^{+}$and $\mathrm{OH}^{-}$can be realized and this can diversify the final products and enhance the purity for nutrient recovery [106]. Combining $\mathrm{H}^{+}$and anions in certain chambers leads to the production of acids, while the combination of cations and $\mathrm{OH}^{-}$leads to the production of the corresponding base. Wang et al. [115] employed the ED process with a bipolar membrane to convert the $\mathrm{P}_{-} \mathrm{PO}_{4}{ }^{3-}$ contained in sludge supernatant to purified phosphoric acid at a concentration of $0.075 \mathrm{~mol} / \mathrm{L}$. Wang et al. [116] conducted 
an experimental study on the recovery of ammonia and $\mathrm{PO}_{4}{ }^{3-}$ by ED integrated with struvite precipitation; ED was mainly employed to obtain a concentrated nutrient salt solution that was fed into the precipitation reactor in order to precipitate $\mathrm{N}$ and $\mathrm{P}$ salts as struvite. By further treating the concentrate solution with ammonia stripping, the authors could obtain a removal ratio of about $95.8-100 \%$ for $\mathrm{NH}_{3}$ and $86.1-94.4 \%$ for $\mathrm{PO}_{4}{ }^{3-}$. In the literature, no studies report on the recovery of potassium from ADS with ED. Nevertheless, there are some useful applications of K recovery from other organic waste substrates. Barros et al. [117], aiming at the generation of a potassium concentrated stream, were able to recover $72 \%$ of potassium from vinasse, which is characterized by a high concentration of $\mathrm{K}^{+}(0.04-11 \mathrm{~g} / \mathrm{L})$.

Table 3. Removal/recovery of N and P from SS and ADS streams through membrane technologies.

\begin{tabular}{|c|c|c|c|c|c|c|c|c|}
\hline Sludge Type & $\begin{array}{l}\text { TS } \\
(\mathrm{g} / \mathrm{L})\end{array}$ & $\mathrm{pH}$ & $\begin{array}{l}\text { Membrane } \\
\text { System }\end{array}$ & $\begin{array}{c}\text { Influent } \\
{\mathrm{N}-\mathrm{NH}_{4}}^{+} \\
(\mathrm{mg} / \mathrm{L})\end{array}$ & $\begin{array}{c}\text { Influent } \\
{\mathrm{P}-\mathrm{PO}_{4}{ }^{3-}}_{(\mathrm{mg} / \mathrm{L})}\end{array}$ & $\begin{array}{c}\text { N Removal } \\
(\%)\end{array}$ & $\begin{array}{c}\text { P Removal } \\
(\%)\end{array}$ & Ref. \\
\hline $\begin{array}{l}\text { Wet-oxidized } \\
\text { ADS and SS }\end{array}$ & $5-20$ & $1.5-2$ & UF-NF & - & $87-152$ & - & $68^{1}$ & [100] \\
\hline $\begin{array}{l}\text { Nutrient-enriched } \\
\text { SS }\end{array}$ & - & 7.2 & $\mathrm{FO}$ & $100-200$ & $100-200$ & $96-98$ & 98-99 & [109] \\
\hline ADS centrate & - & $7-8$ & FO-RO & 1011 & 78 & $83-95$ & 100 & [118] \\
\hline ADS centrate & 1800 & 7.72 & $\begin{array}{l}\text { FO-MD-struvite } \\
\text { precipitation }\end{array}$ & 418 & 73 & 90 & 97 & [113] \\
\hline
\end{tabular}

\subsubsection{Thermal Treatments}

Thermal treatments include incineration, pyrolysis, gasification, and hydrothermal carbonization (HTC), depending on temperature, pressure, and oxygen conditions. Conversion of municipal SS by different thermal processes yields solid residuals (ashes and chars) with significant differences in their composition, values, and qualities [119,120]. Thermal treatments are not applied only to raw SS, but can also be carried out on ADS, providing an energetically favorable treatment cycle, which includes sending the SS to AD to produce biogas and then sending the ADS to thermal treatment [121]. Since the products of thermal processes retain most of the $\mathrm{P}, \mathrm{N}$, and K originally contained in the treated sludge, it is possible to use them directly as soil improvers or to further treat them via chemical and thermochemical routes to release the nutrients [3].

\subsubsection{Incineration}

Due to a significant reduction of the SS volume, thermal degradation of toxic components, and high energy efficiency, incineration is one of the most applied thermal technologies for SS treatment [122]. During the incineration process, combustible material is oxidized and energy is released as thermal energy in the flue gas, while the organic pollutants, endocrine disruptors, and pathogens contained in SS are destroyed, and volatile HMs, such as quicksilver, are transferred to the flue gas. Nutrients, especially $\mathrm{P}$, are not transferred to the flue gas, as they are kept in the incinerator ash [123]. The content of $\mathrm{P}$ in SS is estimated to range from $1 \%$ to $5 \%$, while the P content in SS ash can reach $20 \%$ [41]. As a result, more phosphorus can be recovered per $\mathrm{kg}$ of ashes than of SS. Unfortunately, incineration appears economically viable only in large WWTPs, mainly because of the large capital costs associated with the compliance with ecological criteria. An opportunity could be to exploit existing incineration plants in the vicinity of the WWTPs. Moreover, during the combustion process, phosphorus is transferred into low-solubility mineral phases with low availability for plants. It is therefore necessary to transfer the $\mathrm{P}-\mathrm{PO}_{4}{ }^{3-}$ by means of a suitable thermochemical reaction to a plant-available form [123]. Adam et al. [124] suggested a two-step thermal treatment based on (1) mono-incineration 
of municipal SS, and (2) thermochemical treatment of the resulting ashes. The authors were able to completely remove the critical organic pollutants from mono-incineration, obtaining, as a product, ashes with a $\mathrm{P}_{2} \mathrm{O}_{5}$ content of $21.4 \%$, comparable with conventional P-fertilizers. However, the phosphorus in the raw ashes has a poor bioavailability and high HMs concentrations. Therefore, in a second thermochemical step, HMs are removed and $\mathrm{P}$ is transferred into mineral phases available for plants. Smol et al. [125] thermochemically treated SS ashes coming from mono-incineration, together with sodium additives and a reducing agent (dried SS), to remove HMs and transform the insoluble P present in the SS ashes into $\mathrm{CaNaPO}_{4}$, which is available to plants. The authors also made a comparison between the P solubility in the raw ashes and in the thermochemically treated ashes, using neutral ammonium citrate as a bioavailability indicator, and found that the P solubility was significantly increased from $19.7-45.7 \%$ to $76.5-100 \%$. Nevertheless, P recovery processes mainly aim at separating HMs from the valuable $\mathrm{P}$ and at converting $\mathrm{P}$ to a form readily available to plants for reuse as fertilizer or into a raw material for the P-industry.

Two categories of P recovery technologies are available from SS ashes: wet chemical approaches, and thermal approaches. Thermal approaches separate $\mathrm{P}$ and HMs at temperatures of $1000-2000{ }^{\circ} \mathrm{C}$ and transform $\mathrm{P}$ into a plant-available form $[123,124,126]$, while wet chemical approaches include acid and alkaline dissolution techniques. Chemical extraction is the most used method for its high efficiency and low cost, but it also leaches metal/metalloids present in SS ashes. To recover P from the leachate, it can be precipitated by adjusting the $\mathrm{pH}$ to 4 , but it is necessary to add cations to transform the metal-P precipitates into plant-available fertilizer [126]. However, due to P losses during the purification process, the conventional method for $\mathrm{P}$ extraction results in a low recovery efficiency [127]. To solve this problem, it is necessary to find suitable leaching agents to separate P from metals/metalloids. Organic acids induce chelating effects that greatly increase the leaching of metals/metalloids from ash and soil [126]. Inorganic acids leach alkali metal oxides and release all phases containing $\mathrm{P}$, of which sulfuric acid and nitric acid proved to have a high $P$ releasing capacity $[128,129]$. In order to ameliorate these drawbacks, Petzet et al. [127] developed a combined acid-base extraction procedure: the investigated process requires an acidic pre-treatment in which the $\mathrm{P}$ fraction of the raw SS ashes that is bound as calcium phosphate is converted into aluminum phosphate. This newly formed aluminum phosphate can be dissolved via alkaline treatment and easily separated from the leachate via precipitation of calcium phosphate. The described sequential treatment process yields P-recovery rates as high as 70-77\%. Currently, the recovery of phosphorus from fly ashes is more expensive than the production of $\mathrm{P}$ from phosphorus ores; the former is, therefore, not economically feasible [41,123]. At the same time, a price increase is expected for phosphorus from natural deposits in the future, which may make the costs for phosphorus recovery from SS more competitive [41,130]. N and K cannot be effectively recovered through incineration, as $\mathrm{N}$ is lost as nitrogen gas during combustion, while $\mathrm{K}$ is generally water-soluble and not incorporated into the SS ash [131].

\subsubsection{Pyrolysis and Gasification}

Pyrolysis is the thermal process by which organic material decomposes under oxygenfree atmosphere at ambient pressure and temperatures between 400 and $800{ }^{\circ} \mathrm{C}$ [132]. Differently from incineration, which occurs in the presence of oxygen and above $800^{\circ} \mathrm{C}$, pyrolysis operates in the absence of oxygen and at lower temperatures [3]. Moreover, compared to the incineration process, which is highly exothermic, pyrolysis is endothermic, of the order of $100 \mathrm{~kJ} / \mathrm{kg}$ dry solids [133]. This process generates gas and vapors, and liquid (bio-oil and tar) and solid (biochar) products [134] in a ratio which depends on the process parameters [122]. Due to the anoxic conditions, most of the carbon substances (e.g., cellulose, starch, lignin, and glucose) can be hydrolyzed and converted to biochar, with non-vapor elements coexisting [48]. Pyrolysis can be applied to convert raw, digested and waste-activated SS into syngas and biochar as by-products. It has been estimated that AD of SS followed by pyrolysis yields higher rates of energy recovery than stand-alone AD 
or pyrolysis [135]. Cao and Pawlowski [135] assessed the energy conversion efficiency of two parallel sludge-to-energy pathways: one pathway was based on AD followed by pyrolysis; the other pathway was based on pyrolysis alone. To characterize the energetic performance of the two pathways two indicators were used: the apparent energy efficiency (AEE), i.e., the ratio of the energy content in the target products to the energy content of the sludge feedstock, and the gross energy efficiency (GEE), which also considers the energy in process by-products (e.g., biochar). The results proved that the combination of $\mathrm{AD}$ and pyrolysis achieves higher energy efficiency (AEE 71.4\%-GEE 92.5\%) compared to the pathway employing pyrolysis alone (AEE 60.4\%-GEE 89.8\%).

Although similar to pyrolysis, gasification usually transforms organic materials to combustible gas or syngas, using between $20 \%$ and $40 \%$ of the oxygen required for total combustion [136]. Gasification can limit the problems commonly faced in the incineration process, such as the need for a supplemental fuel; emissions of $\mathrm{SO}_{\mathrm{x}}, \mathrm{NO}_{\mathrm{x}}, \mathrm{HMs}$, and fly; ash as well as the potential production of chlorinated dibenzodioxins and dibenzofurans. The gasification syngas, which is a mixture of $\mathrm{CO}, \mathrm{H}_{2}$, and other gases, has a heating value typically in the range of $4-12 \mathrm{MJ} / \mathrm{Nm}^{3}$. Syngas is limited to local consumption, because its compression, storage, and transport are not economically attractive [136]. To date, pyrolysis and gasification are still poorly applied worldwide for full-scale valorization of SS. The main limitation to the spreading of these processes is the low quality of the obtained products, which require significant treatment before being used for energy and/or material recovery. For instance, tar is a complex mixture of condensable hydrocarbons, phenolic compounds, and HMs, and may cause various operational problems within the plant, e.g., blockage of filters, fuel lines, valves, and fuel injectors of engines. Moreover, tar compounds are a serious concern if released into the environment, being toxic and potentially carcinogenic [137]. The syngas obtained from SS may contain high levels of corrosive gases, i.e., $\mathrm{H}_{2} \mathrm{~S}$ and $\mathrm{HCl}$, and has a lower calorific value compared to biogas (up to $40 \mathrm{MJ} / \mathrm{Nm}^{3}$ ) [138]. Utilization of char in agriculture may be limited by the high concentration of HMs, being mostly retained in the solid residue and concentrated because of the mass reduction resulting from thermal degradation [139].

In terms of nutrient recovery, both pyrolysis and gasification of SS could be coupled for efficient $\mathrm{P}$ removal and recovery. Indeed, the solid residues from pyrolysis and gasification are a sanitized source of minerals and some organic elements, including valuable fertilizing components, such as $\mathrm{P}_{2} \mathrm{O}_{5}, \mathrm{~K}_{2} \mathrm{O}, \mathrm{MgO}$, and $\mathrm{Fe}_{2} \mathrm{O}_{3}$, which makes them a potential substitute for natural phosphorus ore [140]. Pyrolysis can be designed and operated to retain most of the $\mathrm{P}$ and $\mathrm{K}$ and some of the $\mathrm{N}$ in the solid or liquid by-products. Bridle and Pritchard [141] showed that pyrolysis of dried SS pellets performed at $450{ }^{\circ} \mathrm{C}$ at a pressure of $1.5 \mathrm{kPa}$ retained $99 \%$ of $\mathrm{P}$ and $\mathrm{K}$ and $55 \%$ of $\mathrm{N}$ in the char. Results from this study showed that the phosphorus in the char was in its soluble form, available for plants, while nitrogen was in an insoluble form and, thus, less available for plant use. Based on these results, it appears that there is the potential to use pyrolysis as an effective means of recovering and reusing both the energy and phosphorus present in SS [89]. Vali et al. [142] showed that over $90 \%$ of the phosphorus contained in SS was retained in the char after pyrolysis at temperatures up to $850^{\circ} \mathrm{C}$, while higher temperature led to the formation of gaseous $\mathrm{P}$ compounds. At the same time, the concentration of HMs in the char decreased significantly (except $\mathrm{Cu}$ and $\mathrm{Zn}$ ), as most of them were volatilized in the gas phase or solubilized into the aqueous phase. As reported in Table 4, K was also retained in the char at all tested temperatures. The obtained char could be used as soil improver or for further refinery in the fertilizer industry. AtienzaMartínez et al. [143] recovered nearly all phosphorus contained in the gasification ash of SS by extraction with sulfuric and oxalic acid at stoichiometric concentrations. Likewise, Gorazda et al. [140] demonstrated that acidic extraction (with nitric and/or phosphoric acid) was able to recover $P$ with extraction efficiencies of $73-82 \%$, transferring it from solid residue of ADS gasification into a plant-available form in leachates, which can be used for fertilizer production. Other studies confirm the presence of $\mathrm{K}$ in the gasification ashes of SS [144]: 0.55wt\% [145], 4.63wt \% [146], and 1.11wt\% [147]. Nevertheless, these studies did 
not focus on the recovery of this element. The recovery of $\mathrm{N}$ through gasification is not possible, as it is diluted in the form of $\mathrm{N}_{2}$ in the produced syngas [123].

\subsubsection{Hydrothermal Carbonization}

HTC is a hydro-thermal process that takes place in liquid water at temperatures of $180-250{ }^{\circ} \mathrm{C}$, pressure of $60-100 \mathrm{bar}$, and in the absence of oxygen. HTC requires lower temperatures than pyrolysis and gasification, but very high pressure [122]. During the HTC reaction, water, carbon dioxide, and other compounds are generated from the biomass, producing, in less than $10 \mathrm{~h}$, a carbonaceous solid, the biocarbon (or hydrochar-HC), with characteristics similar to lignite, and an aqueous residue rich in the nutrients previously contained in the raw material (process water). The use of water as a solvent is a key factor for HTC, due to its good heat transfer and solvent properties [148]. In recent years, HTC has emerged as a promising technology for sustainable SS minimization and valorization of the solid products [149]. It can significantly reduce SS volume, decompose organic pollutants by hydrolysis and carbonization reactions, and generate valuable byproducts, including the hydrochar and process water [150]. In particular, HTC process water from SS is characterized by a higher nitrogen content than that resulting from the HTC of other biomasses [149]. HTC releases energy through carbonization and increases or maintains the reaction temperature in the HTC reactor, not requiring much additional energy input after the initial heating phase if the reactor energy losses are minimized. Escala et al. [151] calculated the energy balance based on assumptions regarding potential recoverable energy and showed that no additional external energy input is needed to support the reaction process for SS. These results were also confirmed by Aragón-Briceño et al. [152]; the authors demonstrated that the integration of the HTC process to the AD of SS showed a positive energy balance, with a maximum net energy production of $312.9 \mathrm{kWh}$ per ton of treated sludge if the hydrochar is considered as a fuel source; increasing the net energy production 10 times compared to when only biogas is used as energy source.

HTC process water is commonly regarded as a wastewater and needs to be appropriately treated. However, it has a high soluble concentration of both organics and nutrients (particularly ammonia and potassium), allowing a potential application in liquid organic fertilizer production [153]. During HTC, nitrogen and phosphorus migrate from the raw SS to the process water in the form of $\mathrm{NH}_{4}{ }^{+}$and $\mathrm{PO}_{4}{ }^{3-}$, which can be precipitated as struvite. Munir et al. [72] reported that struvite precipitation used as a post-treatment on liquid residue, after SS hydrothermal treatment, was a cost-effective option for $\mathrm{P}_{-} \mathrm{PO}_{4}{ }^{3-}$ recovery. $\mathrm{P}_{-} \mathrm{PO}_{4}{ }^{3-}$ was recovered by adding $\mathrm{MgCl}_{2}$ solution (1000 $\mathrm{ppm}$ ) at $\mathrm{pH} 9$ to facilitate precipitation of struvite. In this way, the struvite production was $9.5 \mathrm{~kg} / \mathrm{m}^{3}$ and $\mathrm{P}_{-} \mathrm{PO}_{4}{ }^{3-}$ recovery of $80 \%$ was obtained. According to Aragón-Briceño et al. [154], the best scenarios for struvite production showed that $0.06 \mathrm{~kg}$ of struvite could be produced per ton of SS when coupling HTC to AD for SS treatment.

Table 4. Recovery of N, P, and K from ADS and SS streams through thermal treatments.

\begin{tabular}{|c|c|c|c|c|c|c|}
\hline Sludge Type & System & $\underset{\left({ }^{\circ} \mathrm{C}\right)}{\mathrm{T}}$ & $\begin{array}{l}\text { Pressure } \\
\quad(\mathrm{kPa})\end{array}$ & Extraction Method & N, P and K Recovery & Ref. \\
\hline Municipal SS & $\begin{array}{l}\text { Incineration/ } \\
\text { gasification }\end{array}$ & 1000 & - & - & $\begin{array}{l}(\% \mathrm{P})_{\text {ASHES }}=11-25 \\
(\% \mathrm{~K})_{\text {ASHES }}=0.6-2.8\end{array}$ & {$[124]$} \\
\hline SS & Pyrolysis & 450 & 1.5 & $\begin{array}{l}\text { Sequential } \\
\text { extraction }\end{array}$ & $\begin{array}{l}(\% N)_{\text {IN CHAR }}=55 \\
(\% \mathrm{P})_{\text {IN CHAR }}=100\end{array}$ & [141] \\
\hline Char from pyrolysis of SS & $\begin{array}{l}\text { Combustion/ } \\
\text { Gasification }\end{array}$ & $600-900$ & - & $\begin{array}{l}\text { Leaching with } \\
\text { oxalic acid }\end{array}$ & $(\% \mathrm{P})_{\text {IN LEACHATE }} \geq 90$ & [143] \\
\hline Dry ADS & Gasification & $800-1000$ & - & $\begin{array}{l}\text { Leaching with nitric } \\
\text { and/or phosphoric acid }\end{array}$ & $\begin{array}{c}(\% \mathrm{P})_{\text {IN SOLID RESIDUE }}=8.76 \\
(\% \mathrm{P})_{\text {IN LEACHATE }}=73.5-81.5 \\
(\%)_{\text {IN SOLID RESIDUE }}=0.703\end{array}$ & [140] \\
\hline SS & HTC & 200 & 2100 & - & $\begin{array}{c}\text { (mg/L in liquid fraction }) \\
\mathrm{N}: 2392-2419 \\
\text { P: 804-813 } \\
\mathrm{K}: 1516-1519\end{array}$ & {$[155]$} \\
\hline
\end{tabular}




\section{Comparative Assessment of the Strategies for Exploiting the Nutrient Potential of ADS}

Based on the above compiled information, a critical comparative overview of the described technologies and strategies for exploiting the nutrient content of ADS is given in this section.

Struvite precipitation/crystallization and ammonia stripping are the most applied technologies for nutrient removal and recovery from ADS at full scale and are typically performed on the liquid fraction of ADS, obtained from the solid-liquid separation commonly carried out within the WWTP by screw press separators, screening drum presses, or decanter centrifuges. Solid-liquid separation reduces the transportation cost of the digestate [156] and avoids clogging in the struvite crystallizer (usually a fluidized-bed or a mechanically stirred reactor) [157] and stripping column (being fed with the liquid fraction only) [158].

Table 5 lists the costs of the different technologies that can be applied for nutrient recovery from ADS. Struvite crystallization is the most expensive approach for nutrient recovery, although it results in the production of the most valuable recovery product (struvite) from ADS processing. Both struvite precipitation and ammonia stripping from the liquid fraction of ADS are not viable strategies when the removal of ammonia must be carried out to avoid inhibition of the process, such as during HSAD of SS, due to the high sludge viscosity. The application of a new technology, i.e., TFE, enables directly stripping ammonia from the digesting sludge $[52,55,56]$, resulting in a powerful means for simultaneous process non-inhibition and two-fold production of fertilizers (high-solid ADS and ammonium sulfate) at full scale. Moreover, struvite precipitation during HSAD further increases the agronomic value of the produced ADS, promoting its application and public acceptance as a fertilizer, and can be also regarded as an alternative method of avoiding ammonia inhibition during HSAD of SS, as it can limit the build-up of ammonia in the digester.

$\mathrm{Mg}$ is commonly the limiting element for struvite precipitation. To promote the application of struvite precipitation at real scale, a cheaper source of $\mathrm{Mg}$ should be utilized. This could be obtained by combining struvite precipitation with other technologies, e.g., coupling struvite precipitation to ion exchange with zeolite. Natural zeolite can be modified by incorporating magnesium salts, and the $\mathrm{Mg}^{2+}$ released from the adsorption process can promote struvite crystallization [159]. In the hybrid process, zeolite rich in $\mathrm{N}$ and $\mathrm{P}$ removed from ADS could be used as a nutrient source for fertilizer production, partly recovering the costs for the purchase of zeolites. This would promote the use of zeolite for nutrient recovery, as, to date, no application has been reported at full-scale and no cost-benefit analyses exist in the literature for nutrient recovery from ADS using zeolites. Future research could be directed towards an assessment of the market value of recovered $\mathrm{N}$ - and P-rich zeolite, to be used as a slow-release fertilizer.

Membrane technologies can efficiently concentrate nutrients. However, the operating costs of the process at full scale, which are closely linked to power consumption, cleaning frequency, and membrane replacement, need further investigation. Future studies will have to find solutions to improving membrane filtration performance, in terms of chemical and energy requirements, which can be achieved by limiting the fouling problem and utilizing renewable energy sources. It is worth highlighting that a comprehensive analysis of the costs of membrane filtration should consider the possible final reuse of the permeate and concentrate, which in turn are region specific. However, membrane processes are not as versatile for nutrient recovery as other options discussed in this study; for instance, high-solid substrates are not likely to be conveniently addressed by this technology because they would worsen fouling issues and increase the process complexity.

From a wider perspective, it should be also noted that most technologies for nutrient recovery have been investigated on both SS and ADS. The advantage of using ADS within these processes lays in the possibility of taking the greatest advantage of the SS by exploiting not only its nutrient content, but also its biochemical potential for biogas generation. HSAD of SS seems the most efficient strategy for exploiting the nutrient potential of SS, 
as it results in the production of ADS with a significant agronomic value in terms of humified organic matter and nutrient concentrations, which can be directly injected into the soil (if compliant with the established regulations), and ammonium sulfate/nitrate as an additional fertilizer. Thermal treatments allow obtaining ash/char, from which a high recovery rate of nutrients can be reached. Nevertheless, thermal treatments are highly energy-consuming and require expensive emission control and further downstream gas treatment for pollutant mitigation. Due to these drawbacks, which increase the complexity of the process and capital costs and reduce the energy conversion efficiency, this technology seems the least promising. However, to improve the energy balance of the cycle, thermal treatments could be integrated with $\mathrm{AD}$, in order to generate biogas as well as energy and nutrient-rich products. From this point of view, the choice of coupling thermal treatments to AD could represent a convenient alternative to direct SS treatment, although in some cases it represents an obvious choice, for example when the produced ADS cannot be directly used in agriculture, due to low quality (e.g., high concentrations of HMs and /or other contaminants) or not being compatible with the local regulation for agricultural use.

Table 5. Cost estimation of different strategies for nutrient recovery from ADS.

\begin{tabular}{|c|c|c|c|}
\hline Technology & Process Cost & $\begin{array}{c}\text { Marketing Value of } \\
\text { Recovered } \\
\text { End-Products }\end{array}$ & Ref. \\
\hline $\begin{array}{l}\text { Side-stream ammonia } \\
\text { stripping } \\
\text { coupled to HSAD }\end{array}$ & $1.17-1.83 € / \mathrm{kg} \mathrm{N}$ & $0.77 € / \mathrm{kg} \mathrm{N}^{1}$ & $\begin{array}{c}\text { This study } \\
\text { [160] }\end{array}$ \\
\hline Ammonia stripping & $2-7 € / \mathrm{kg} \mathrm{N}$ & $0.77 € / \mathrm{kg} \mathrm{N}$ & {$[160,161]$} \\
\hline Struvite precipitation & $\begin{array}{l}9-49 € / \mathrm{kg} \mathrm{N} \\
4-22 € / \mathrm{kg} \mathrm{P}\end{array}$ & $\begin{array}{c}0.79-5.50 € / \mathrm{kg} \mathrm{N} \\
0.36-2.49 € / \mathrm{kg} \mathrm{P}\end{array}$ & {$[81,162]$} \\
\hline Membrane filtration & $4-5 € / \mathrm{kg} \mathrm{P}^{2}$ & $\begin{array}{c}0.11-0.42 € / \mathrm{kg} \mathrm{N}^{3} \\
2.0-2.1 € / \mathrm{kg} \mathrm{P}^{3} \\
0.11-0.30 € / \mathrm{kg} \mathrm{K}^{3}\end{array}$ & {$[81,105]$} \\
\hline Thermal treatment & $2-6 € / \mathrm{kg} \mathrm{P}^{4}$ & $0.85-4.25 € / \mathrm{kg} \mathrm{P}$ & [163-165] \\
\hline
\end{tabular}

\section{Conclusions}

This review outlines the potential for nutrient recovery from SS and its anaerobically digested form in a sustainable context. Various technologies were classified for their ability to recover a specific nutrient (e.g., nitrogen with ammonia stripping) or to allow the simultaneous recovery of multiple nutrients (struvite precipitation, ion exchange, membrane technologies, and thermal treatments followed by nutrient extraction techniques) and critically discussed to shed light on the state of the art, recent advances, opportunities, challenges, and feasibility for full-scale application.

It is evident that both SS and ADS can be considered as a resource to be exploited from a circular economy perspective. The use of ADS appears as the more convenient option, as it allows both the recovery of energy via biogas generation and nutrients via different strategies, resulting in a positive energy balance and wider applicability for nutrient recycling. From this perspective, HSAD can be considered as a promising and convenient option for simple, direct, and full exploitation of the nutrient potential of ADS, due to the possibility of producing a digestate that, compared to the conventional one, has a higher agronomic value. Nevertheless, HSAD needs further technological improvements, in terms of the energy recovery from SS, as well as a wider acceptance of ADS utilization in agriculture, which needs to be enhanced both at social and legislative levels. Further research is also needed in the field of struvite precipitation from ADS, since this can be regarded as a strategy to recover valuable nutrients, while reducing the formation of undesired deposits within the digesters. In this context, lab scale trials to unveil the 
formation and precipitation mechanisms should be combined with full-scale investigations to address the definition of sustainable technical solutions, fully implementing circular economy principles in SS management.

Author Contributions: Conceptualization: N.D.C., A.C., F.D.C. and G.E.; writing-original draft preparation: N.D.C., A.C. and F.D.C.; writing-review and editing: N.D.C., A.C., F.D.C. and G.E.; visualization: N.D.C., A.C. and F.D.C.; supervision: A.C., F.D.C. and G.E.; project administration: A.C., F.D.C. and G.E.; funding acquisition: F.D.C. and G.E. All authors have read and agreed to the published version of the manuscript.

Funding: This research was funded by Istituto Nazionale Previdenza Sociale (INPS) and Programma Operativo Nazionale (PON) 2014/2020-BIOFEEDSTOCK Project.

Institutional Review Board Statement: Not applicable.

Informed Consent Statement: Not applicable.

Data Availability Statement: Not applicable.

Acknowledgments: Alessandra Cesaro would like to thank the former Italian Ministry of Education, University and Research (MIUR) who provided financial support for her position as Assistant Professor in the frame of the research project entitled "Dipartimenti di Eccellenza" per Ingegneria Civile Edile e Ambientale-CUPE65D18000820006.

Conflicts of Interest: The authors declare that they have no known competing financial interests or personal relationships that could have appeared to influence the work reported in this paper.

\section{References}

1. Shaddel, S.; Bakhtiary-Davijany, H.; Kabbe, C.; Dadgar, F.; Østerhus, S.W. Sustainable sewage sludge management: From current practices to emerging nutrient recovery technologies. Sustainability 2019, 11, 3435. [CrossRef]

2. Siciliano, A.; Limonti, C.; Curcio, G.M.; Molinari, R. Advances in struvite precipitation technologies for nutrients removal and recovery from aqueous waste and wastewater. Sustainability 2020, 12, 7538. [CrossRef]

3. Mehta, C.M.; Khunjar, W.O.; Nguyen, V.; Tait, S.; Batstone, D.J. Technologies to recover nutrients from waste streams: A critical review. Crit. Rev. Environ. Sci. Technol. 2015, 45, 385-427. [CrossRef]

4. Bolzonella, D.; Fatone, F.; Gottardo, M.; Frison, N. Nutrients recovery from anaerobic digestate of agro-waste: Techno-economic assessment of full scale applications. J. Environ. Manag. 2018, 216, 111-119. [CrossRef]

5. Alhnidi, M.J.; Wüst, D.; Funke, A.; Hang, L.; Kruse, A. Fate of Nitrogen, Phosphate, and Potassium during Hydrothermal Carbonization and the Potential for Nutrient Recovery. ACS Sustain. Chem. Eng. 2020, 8, 15507-15516. [CrossRef]

6. Raheem, A.; Sikarwar, V.S.; He, J.; Dastyar, W.; Dionysiou, D.D.; Wang, W.; Zhao, M. Opportunities and challenges in sustainable treatment and resource reuse of sewage sludge: A review. Chem. Eng. J. 2018, 337, 616-641. [CrossRef]

7. Lebuf, V.; Accoe, F.; Vaneeckhaute, C.; Meers, E.; Michels, E.; Ghekiere, G. Nutrient recovery from digestates: Techniques and end-products. In Proceedings of the Fourth International Symposium on Energy from Biomass and Waste, Venice, Italy, 12 November 2012; p. 18.

8. Stevens, C.J. Nitrogen in the environment. Science 2019, 363, 578-580. [CrossRef] [PubMed]

9. Stein, L.Y.; Klotz, M.G. The nitrogen cycle. Curr. Biol. 2016, 26, R94-R98. [CrossRef]

10. Mikkelsen, R.L. Managing potassium for organic crop production. Horttechnology 2007, 17, 455-460. [CrossRef]

11. Zapata, F.; Roy, R.N. Use of phosphate rocks for sustainable agriculture. FAO Fertil. Plant Nutr. Bull. 2004, 35, 1-148.

12. Chowdhury, R.B.; Moore, G.A.; Weatherley, A.J.; Arora, M. Key sustainability challenges for the global phosphorus resource, their implications for global food security, and options for mitigation. J. Clean. Prod. 2017, 140, 945-963. [CrossRef]

13. European Commission. Circular economy action plan. In Proceedings of the European Commission, Bruxelles, Belgium, 3 November 2020.

14. Di Capua, F.; Spasiano, D.; Giordano, A.; Adani, F.; Fratino, U.; Pirozzi, F.; Esposito, G. High-solid anaerobic digestion of sewage sludge: Challenges and opportunities. Appl. Energy 2020, 278, 115608. [CrossRef]

15. Saliu, T.D.; Oladoja, N.A. Nutrient recovery from wastewater and reuse in agriculture: A review. Environ. Chem. Lett. 2021, 19, 2299-2316. [CrossRef]

16. Ye, Y.; Ngo, H.H.; Guo, W.; Chang, S.W.; Nguyen, D.D.; Zhang, X.; Zhang, J.; Liang, S. Nutrient recovery from wastewater: From technology to economy. Bioresour. Technol. Rep. 2020, 11, 100425. [CrossRef]

17. Macura, B.; Johannesdottir, S.L.; Piniewski, M.; Haddaway, N.R.; Kvarnström, E. Effectiveness of ecotechnologies for recovery of nitrogen and phosphorus from anaerobic digestate and effectiveness of the recovery products as fertilisers: A systematic review protocol. Environ. Evid. 2019, 8, 29. [CrossRef]

18. Morales, N.; Boehler, M.A.; Buettner, S.; Liebi, C.; Siegrist, H. Recovery of N and P from urine by struvite precipitation followed by combined stripping with digester sludge liquid at full scale. Water 2013, 5, 1262-1278. [CrossRef] 
19. Liu, B.; Giannis, A.; Zhang, J.; Chang, V.W.C.; Wang, J.Y. Air stripping process for ammonia recovery from source-separated urine: Modeling and optimization. J. Chem. Technol. Biotechnol. 2015, 90, 2208-2217. [CrossRef]

20. Caspersen, S.; Ganrot, Z. Closing the loop on human urine: Plant availability of zeolite-recovered nutrients in a peat-based substrate. J. Environ. Manag. 2018, 211, 177-190. [CrossRef]

21. Foletto, E.L.; Dos Santos, W.R.B.; Mazutti, M.A.; Jahn, S.L.; Gündel, A. Production of struvite from beverage waste as Phosphorus source. Mater. Res. 2013, 16, 242-245. [CrossRef]

22. Huang, H.; Song, Q.; Wang, W.; Wu, S.; Dai, J. Treatment of anaerobic digester effluents of nylon wastewater through chemical precipitation and a sequencing batch reactor process. J. Environ. Manag. 2012, 30, 68-74. [CrossRef]

23. Healy, M.G.; Clarke, R.; Peyton, D.; Cummins, E.; Moynihan, E.L.; Martins, A.; Fenton, O. Resource recovery from sewage sludge. Water Intell. Online 2015, 14, 139-163.

24. Adam, C.; Kley, G.; Simon, F.-G.; Lehmann, A. Recovery of nutrients from sewage sludge - Results of the European researchproject SUSAN. Water Pract. Technol. 2008, 3, wpt2008001. [CrossRef]

25. Mulchandani, A.; Westerhoff, P. Recovery opportunities for metals and energy from sewage sludges. Bioresour. Technol. 2016, 215, 215-226. [CrossRef] [PubMed]

26. Hidalgo, D.; Corona, F.; Martín-Marroquín, J.M.; del Álamo, J.; Aguado, A. Resource recovery from anaerobic digestate: Struvite crystallisation versus ammonia stripping. Desalin. Water Treat. 2016, 57, 2626-2632. [CrossRef]

27. Zhen, G.; Lu, X.; Kato, H.; Zhao, Y.; Li, Y.Y. Overview of pretreatment strategies for enhancing sewage sludge disintegration and subsequent anaerobic digestion: Current advances, full-scale application and future perspectives. Renew. Sustain. Energy Rev. 2017, 69, 559-577. [CrossRef]

28. Liao, X.; Li, H.; Zhang, Y.; Liu, C.; Chen, Q. Accelerated high-solids anaerobic digestion of sewage sludge using low-temperature thermal pretreatment. Int. Biodeterior. Biodegrad. 2016, 106, 141-149. [CrossRef]

29. Duan, N.; Dong, B.; Wu, B.; Dai, X. High-solid anaerobic digestion of sewage sludge under mesophilic conditions: Feasibility study. Bioresour. Technol. 2012, 104, 150-156. [CrossRef] [PubMed]

30. Scaglia, B.; Tambone, F.; Corno, L.; Orzi, V.; Lazzarini, Y.; Garuti, G.; Adani, F. Potential agronomic and environmental properties of thermophilic anaerobically digested municipal sewage sludge measured by an unsupervised and a supervised chemometric approach. Sci. Total Environ. 2018, 637-638, 791-802. [CrossRef]

31. Scaglia, B.; D’Imporzano, G.; Garuti, G.; Negri, M.; Adani, F. Sanitation ability of anaerobic digestion performed at different temperature on sewage sludge. Sci. Total Environ. 2014, 466-467, 888-897. [CrossRef] [PubMed]

32. Orzi, V.; Scaglia, B.; Lonati, S.; Riva, C.; Boccasile, G.; Alborali, G.L.; Adani, F. The role of biological processes in reducing both odor impact and pathogen content during mesophilic anaerobic digestion. Sci. Total Environ. 2015, 526, 116-126. [CrossRef]

33. Pigoli, A.; Zilio, M.; Tambone, F.; Mazzini, S.; Schepis, M.; Meers, E.; Schoumans, O.; Giordano, A.; Adani, F. Thermophilic anaerobic digestion as suitable bioprocess producing organic and chemical renewable fertilizers: A full-scale approach. Waste Manag. 2021, 124, 356-367. [CrossRef]

34. Zhang, D.; Du, G.; Chen, D.; Shi, G.; Rao, W.; Li, X.; Jiang, Y.; Liu, S.; Wang, D. Effect of elemental sulfur and gypsum application on the bioavailability and redistribution of cadmium during rice growth. Sci. Total Environ. 2019, 657, 1460-1467. [CrossRef] [PubMed]

35. Romero-güiza, M.S.; Mata-alvarez, J.; María, J.; Rivera, C. Nutrient recovery technologies for anaerobic digestion systems: An overview Tecnologías de recuperación de nutrientes para los sistemas de digestión anaeróbica: Revisión Tecnologias de recuperação de nutrientes para os. Bucaramanga 2015, 29, 7-26. [CrossRef]

36. Capson-Tojo, G.; Moscoviz, R.; Astals, S.; Robles, Á.; Steyer, J.P. Unraveling the literature chaos around free ammonia inhibition in anaerobic digestion. Renew. Sustain. Energy Rev. 2020, 117, 109487. [CrossRef]

37. Yuan, H.; Zhu, N. Progress in inhibition mechanisms and process control of intermediates and by-products in sewage sludge anaerobic digestion. Renew. Sustain. Energy Rev. 2016, 58, 429-438. [CrossRef]

38. Daneshgar, S.; Callegari, A.; Capodaglio, A.G.; Vaccari, D. The potential phosphorus crisis: Resource conservation and possible escape technologies: A review. Resources 2018, 7, 37. [CrossRef]

39. Pepè Sciarria, T.; Vacca, G.; Tambone, F.; Trombino, L.; Adani, F. Nutrient recovery and energy production from digestate using microbial electrochemical technologies (METs). J. Clean. Prod. 2019, 208, 1022-1029. [CrossRef]

40. Henze, M.; van Loosdrecht, M.C.M.; Ekama, G.A.; Brdjanovic, D. Biological Wastewater Treatment: Principles, Modelling and Design; IWA Publishing: London, UK, 2008.

41. Cieślik, B.; Konieczka, P. A review of phosphorus recovery methods at various steps of wastewater treatment and sewage sludge management. The concept of "no solid waste generation" and analytical methods. J. Clean. Prod. 2017, 142, 1728-1740. [CrossRef]

42. Le Corre, K.S.; Valsami-Jones, E.; Hobbs, P.; Parsons, S.A. Phosphorus recovery from wastewater by struvite crystallization: A review. Crit. Rev. Environ. Sci. Technol. 2009, 39, 433-477. [CrossRef]

43. Abeysiriwardana-Arachchige, I.S.A.; Munasinghe-Arachchige, S.P.; Delanka-Pedige, H.M.K.; Nirmalakhandan, N. Removal and recovery of nutrients from municipal sewage: Algal vs. conventional approaches. Water Res. 2020, 175, 115709. [CrossRef]

44. Iannacone, F.; Di Capua, F.; Granata, F.; Gargano, R.; Esposito, G. Simultaneous nitrification, denitrification and phosphorus removal in a continuous-flow moving bed biofilm reactor alternating microaerobic and aerobic conditions. Bioresour. Technol. 2020, 310, 123453. [CrossRef] 
45. Iannacone, F.; Di Capua, F.; Granata, F.; Gargano, R.; Esposito, G. Shortcut nitrification-denitrification and biological phosphorus removal in acetate- and ethanol-fed moving bed biofilm reactors under microaerobic/aerobic conditions. Bioresour. Technol. 2021, 330, 124958. [CrossRef]

46. Öborn, I.; Andrist-Rangel, Y.; Askegaard, M.; Grant, C.A.; Watson, C.A.; Edwards, A.C. Critical aspects of potassium management in agricultural systems. Soil Use Manag. 2005, 21, 102-112. [CrossRef]

47. Tambone, F.; Scaglia, B.; D’Imporzano, G.; Schievano, A.; Orzi, V.; Salati, S.; Adani, F. Assessing amendment and fertilizing properties of digestates from anaerobic digestion through a comparative study with digested sludge and compost. Chemosphere 2010, 81, 577-583. [CrossRef] [PubMed]

48. Giordano, A.; Di Capua, F.; Esposito, G.; Pirozzi, F. Long-term biogas desulfurization under different microaerobic conditions in full-scale thermophilic digesters co-digesting high-solid sewage sludge. Int. Biodeterior. Biodegrad. 2019, 142, 131-136. [CrossRef]

49. Shi, L.; Simplicio, W.S.; Wu, G.; Hu, Z.; Hu, H.; Zhan, X. Nutrient Recovery from Digestate of Anaerobic Digestion of Livestock Manure: A Review. Curr. Pollut. Rep. 2018, 4, 74-83. [CrossRef]

50. Arogo, J.; Zhang, R.H.; Riskowski, G.L.; Christianson, L.L.; Day, D.L. Mass transfer coefficient of ammonia in liquid swine manure and aqueous solutions. J. Agric. Eng. Res. 1999, 73, 77-86. [CrossRef]

51. Guštin, S.; Marinšek-Logar, R. Effect of $\mathrm{pH}$, temperature and air flow rate on the continuous ammonia stripping of the anaerobic digestion effluent. Process Saf. Environ. Prot. 2011, 89, 61-66. [CrossRef]

52. Di Capua, F.; Adani, F.; Pirozzi, F.; Esposito, G.; Giordano, A. Air side-stream ammonia stripping in a thin film evaporator coupled to high-solid anaerobic digestion of sewage sludge: Process performance and interactions. J. Environ. Manag. 2021, $295,113075$. [CrossRef]

53. Drosg, B.; Fuchs, W.; Al Seadi, T.; Madsen, M.; Linke, B. Nutrient Recovery by Biogas Digestate Processing; IEA Bioenergy: Dublin, Ireland, 2015; pp. 1-40.

54. Nakashimada, Y.; Ohshima, Y.; Minami, H.; Yabu, H.; Namba, Y.; Nishio, N. Ammonia-methane two-stage anaerobic digestion of dehydrated waste-activated sludge. Appl. Microbiol. Biotechnol. 2008, 79, 1061-1069. [CrossRef]

55. Costamagna, P.; Giordano, A.; Lazzarini, Y.; Delucchi, M.; Busca, G. Process of ammonia removal from anaerobic digestion and associated ammonium sulphate production: Pilot plant demonstration. J. Environ. Manag. 2020, 259, 109841. [CrossRef] [PubMed]

56. Costamagna, P.; Delucchi, M.; Busca, G.; Giordano, A. System for ammonia removal from anaerobic digestion and associated ammonium sulfate production: Simulation and design considerations. Process Saf. Environ. Prot. 2020, 144, 133-142. [CrossRef]

57. Lei, X.; Sugiura, N.; Feng, C.; Maekawa, T. Pretreatment of anaerobic digestion effluent with ammonia stripping and biogas purification. J. Hazard. Mater. 2007, 145, 391-397. [CrossRef] [PubMed]

58. Pedizzi, C.; Lema, J.M.; Carballa, M. A combination of ammonia stripping and low temperature thermal pre-treatment improves anaerobic post-digestion of the supernatant from organic fraction of municipal solid waste treatment. Waste Manag. 2018, 78, 271-278. [CrossRef] [PubMed]

59. Walker, M.; Iyer, K.; Heaven, S.; Banks, C.J. Ammonia removal in anaerobic digestion by biogas stripping: An evaluation of process alternatives using a first order rate model based on experimental findings. Chem. Eng. J. 2011, 178, 138-145. [CrossRef]

60. Tansel, B.; Lunn, G.; Monje, O. Struvite formation and decomposition characteristics for ammonia and phosphorus recovery: A review of magnesium-ammonia-phosphate interactions. Chemosphere 2018, 194, 504-514. [CrossRef]

61. Wilsenach, J.A.; Schuurbiers, C.A.H.; van Loosdrecht, M.C.M. Phosphate and potassium recovery from source separated urine through struvite precipitation. Water Res. 2007, 41, 458-466. [CrossRef] [PubMed]

62. Larsen, T.A.; Udert, K.M.; Lienert, J. Source Separation and Decentralization for Wastewater Management; IWA Publishing: London, UK, 2019; ISBN 9781780401072.

63. Shih, K.; Yan, H. The Crystallization of Struvite and Its Analog (K-Struvite) From Waste Streams for Nutrient Recycling. Environ. Mater. Waste Resour. Recover. Pollut. Prev. 2016, 26, 665-686. [CrossRef]

64. Graeser, S.; Postl, W.; Bojar, H.-P.; Berlepsch, P.; Armbruster, T.; Raber, T.; Ettinger, K.; Walter, F. Struvite-(K), $\mathrm{KM}_{\mathrm{g}} \mathrm{PO}_{4} \cdot 6 \mathrm{H}_{2} \mathrm{O}$, the potassium equivalent of struvite-A new mineral. ECS J. Solid State Sci. Technol. 2008, 20, 629-633. [CrossRef]

65. Xu, K.; Li, J.; Zheng, M.; Zhang, C.; Xie, T.; Wang, C. The precipitation of magnesium potassium phosphate hexahydrate for P and K recovery from synthetic urine. Water Res. 2015, 80, 71-79. [CrossRef] [PubMed]

66. Lorick, D.; Macura, B.; Ahlström, M.; Grimvall, A.; Harder, R. Effectiveness of struvite precipitation and ammonia stripping for recovery of phosphorus and nitrogen from anaerobic digestate: A systematic review. Environ. Evid. 2020, 9, 27. [CrossRef]

67. Dhakal, S. A laboratory study of struvite precipitation for phosphorus removal from concentrated animal feeding operation wastewater. J. Environ. Eng. 2008, 6724, 14-39.

68. Wang, J.; Burken, J.G.; Zhang, X.J. Effect of Seeding Materials and Mixing Strength on Struvite Precipitation. Water Environ. Res. 2006, 78, 125-132. [CrossRef] [PubMed]

69. Parsons, S.A.; Doyle, J.D. Struvite formation, control and recovery. Water Res. 2002, 36, 3925-3940.

70. Fattah, K.P.; Sabrina, N.; Mavinic, D.S.; Koch, F.A. Reducing operating costs for struvite formation with a carbon dioxide stripper. Water Sci. Technol. 2008, 58, 957-962. [CrossRef]

71. Uysal, A.; Yilmazel, Y.D.; Demirer, G.N. The determination of fertilizer quality of the formed struvite from effluent of a sewage sludge anaerobic digester. J. Hazard. Mater. 2010, 181, 248-254. [CrossRef] [PubMed]

72. Kataki, S.; West, H.; Clarke, M.; Baruah, D.C. Phosphorus recovery as struvite: Recent concerns for use of seed, alternative Mg source, nitrogen conservation and fertilizer potential. Resour. Conserv. Recycl. 2016, 107, 142-156. [CrossRef] 
73. Munir, M.T.; Li, B.; Boiarkina, I.; Baroutian, S.; Yu, W.; Young, B.R. Phosphate recovery from hydrothermally treated sewage sludge using struvite precipitation. Bioresour. Technol. 2017, 239, 171-179. [CrossRef] [PubMed]

74. Marti, N.; Bouzas, A.; Seco, A.; Ferrer, J. Struvite precipitation assessment in anaerobic digestion processes. Chem. Eng. J. 2008, 141, 67-74. [CrossRef]

75. Zheng, W.; Li, X.; Li, B. High-quality Magnesium Ammonium Phosphate produced from Digested Sewage Sludge by Adsorption Fresenius Environ. Bull. 2014, 23, 755-761.

76. Xavier, L.D.; Cammarota, M.C.; Yokoyama, L.; Volschan, I. Study of the recovery of phosphorus from struvite precipitation in supernatant line from anaerobic digesters of sludge. Water Sci. Technol. Water Supply 2014, 14, 751-757. [CrossRef]

77. Jia, G.; Zhang, H.; Krampe, J.; Muster, T.; Gao, B.; Zhu, N.; Jin, B. Applying a chemical equilibrium model for optimizing struvite precipitation for ammonium recovery from anaerobic digester effluent. J. Clean. Prod. 2017, 147, 297-305. [CrossRef]

78. Pastor, L.; Marti, N.; Bouzas, A.; Seco, A. Sewage sludge management for phosphorus recovery as struvite in EBPR wastewater treatment plants. Bioresour. Technol. 2008, 99, 4817-4824. [CrossRef] [PubMed]

79. Wacławek, S.; Grübel, K.; Dennis, P.; Vinod, V.T.P.; Černík, M. A novel approach for simultaneous improvement of dewaterability, post-digestion liquor properties and toluene removal from anaerobically digested sludge. Chem. Eng. J. 2016, 291, 192-198. [CrossRef]

80. Li, B.; Boiarkina, I.; Yu, W.; Huang, H.M.; Munir, T.; Wang, G.Q.; Young, B.R. Phosphorous recovery through struvite crystallization: Challenges for future design. Sci. Total Environ. 2019, 648, 1244-1256. [CrossRef]

81. Krakat, N.; Anjum, R.; Dietz, D.; Demirel, B. Methods of ammonia removal in anaerobic digestion: A review. Water Sci. Technol. 2017, 76, 1925-1938. [CrossRef] [PubMed]

82. Vaneeckhaute, C.; Lebuf, V.; Michels, E.; Belia, E.; Vanrolleghem, P.A.; Tack, F.M.G.; Meers, E. Nutrient Recovery from Digestate: Systematic Technology Review and Product Classification. Waste Biomass Valorization 2017, 8, 21-40. [CrossRef]

83. Seruga, P.; Krzywonos, M.; Pyzanowska, J.; Urbanowska, A.; Pawlak-Kruczek, H.; Niedźwiecki, Ł. Removal of ammonia from the municipal waste treatment effuents using natural minerals. Molecules 2019, 24, 3633. [CrossRef]

84. Taddeo, R.; Prajapati, S.; Lepistö, R. Optimizing ammonium adsorption on natural zeolite for wastewaters with high loads of ammonium and solids. J. Porous Mater. 2017, 24, 1545-1554. [CrossRef]

85. Zarebska, A.; Romero Nieto, D.; Christensen, K.V.; Fjerbæk Søtoft, L.; Norddahl, B. Ammonium fertilizers production from manure: A critical review. Crit. Rev. Environ. Sci. Technol. 2015, 45, 1469-1521. [CrossRef]

86. Lin, L.; Lei, Z.; Wang, L.; Liu, X.; Zhang, Y.; Wan, C.; Lee, D.J.; Tay, J.H. Adsorption mechanisms of high-levels of ammonium onto natural and NaCl-modified zeolites. Sep. Purif. Technol. 2013, 103, 15-20. [CrossRef]

87. Zabochnicka-Światek, M.; Malińska, K. Removal of ammonia by clinoptilolite. Glob. Nest J. 2010, 12, 256-261. [CrossRef]

88. Capodaglio, A.G.; Hlavínek, P.; Raboni, M. Physico-chemical technologies for nitrogen removal from wastewaters: A review. Rev. Ambient. e Agua 2015, 10, 481-498. [CrossRef]

89. Kabdaşl1, I.; Tünay, O. Nutrient recovery by struvite precipitation, ion exchange and adsorption from source-separated human urine-a review. Environ. Technol. Rev. 2018, 7, 106-138. [CrossRef]

90. Takaya, C.A.; Fletcher, L.A.; Singh, S.; Anyikude, K.U.; Ross, A.B. Phosphate and ammonium sorption capacity of biochar and hydrochar from different wastes. Chemosphere 2016, 145, 518-527. [CrossRef] [PubMed]

91. Guo, X.F.; Ji, Z.Y.; Yuan, J.S.; Zhao, Y.Y.; Liu, J. Recovery of $\mathrm{K}^{+}$from concentrates from brackish and seawater desalination with modified clinoptilolite. Desalin. Water Treat. 2016, 57, 6829-6837. [CrossRef]

92. Polat, E.; Karaca, M.; Demir, H.; Onus, A.N. Use of natural zeolite (clinoptilolite) in agriculture. J. Fruit Ornam. Plant Res. 2004, 12, 183-189.

93. Wirthensohn, T.; Waeger, F.; Jelinek, L.; Fuchs, W. Ammonium removal from anaerobic digester effluent by ion exchange. Water Sci. Technol. 2009, 60, 201-210. [CrossRef] [PubMed]

94. Thornton, A.; Pearce, P.; Parsons, S.A. Ammonium removal from digested sludge liquors using ion exchange. Water Res. 2007, 41, 433-439. [CrossRef] [PubMed]

95. Kocatürk-Schumacher, N.P.; Bruun, S.; Zwart, K.; Jensen, L.S. Nutrient Recovery From the Liquid Fraction of Digestate by Clinoptilolite. Clean Soil Air Water 2017, 45, 1500153. [CrossRef]

96. Gong, H.; Wang, Z.; Zhang, X.; Jin, Z.; Wang, C.; Zhang, L.; Wang, K. Organics and nitrogen recovery from sewage via membrane-based pre-concentration combined with ion exchange process. Chem. Eng. J. 2017, 311, 13-19. [CrossRef]

97. Lebuf, V.; Accoe, F.; Van Elsacker, S.; Vaneeckhaute, C. Techniques for Nutrient Recovery from Digestate; INTERREG IV.B NWE ARBOR: Brugge, Belgium, 2013; pp. 1-28.

98. Guo, W.; Ngo, H.H.; Li, J. A mini-review on membrane fouling. Bioresour. Technol. 2012, 122, 27-34. [CrossRef] [PubMed]

99. Scholz, W.; Lucas, M. Techno-economic evaluation of membrane filtration for the recovery and re-use of tanning chemicals. Water Res. 2003, 37, 1859-1867. [CrossRef]

100. Gerardo, M.L.; Zacharof, M.P.; Lovitt, R.W. Strategies for the recovery of nutrients and metals from anaerobically digested dairy farm sludge using cross-flow microfiltration. Water Res. 2013, 47, 4833-4842. [CrossRef]

101. Blöcher, C.; Niewersch, C.; Melin, T. Phosphorus recovery from sewage sludge with a hybrid process of low pressure wet oxidation and nanofiltration. Water Res. 2012, 46, 2009-2019. [CrossRef] [PubMed]

102. Waeger, F.; Delhaye, T.; Fuchs, W. The use of ceramic microfiltration and ultrafiltration membranes for particle removal from anaerobic digester effluents. Sep. Purif. Technol. 2010, 73, 271-278. [CrossRef] 
103. Mamo, J.; García-Galán, M.J.; Stefani, M.; Rodríguez-Mozaz, S.; Barceló, D.; Monclús, H.; Rodriguez-Roda, I.; Comas, J. Fate of pharmaceuticals and their transformation products in integrated membrane systems for wastewater reclamation. Chem. Eng. J. 2018, 331, 450-461. [CrossRef]

104. Chon, K.; KyongShon, H.; Cho, J. Membrane bioreactor and nanofiltration hybrid system for reclamation of municipal wastewater: Removal of nutrients, organic matter and micropollutants. Bioresour. Technol. 2012, 122, 181-188. [CrossRef] [PubMed]

105. Asik, G.; Yilmaz, T.; Di Capua, F.; Ucar, D.; Esposito, G.; Sahinkaya, E. Sequential sulfur-based denitrification/denitritation and nanofiltration processes for drinking water treatment. J. Environ. Manag. 2021, 295, 113083. [CrossRef]

106. Nir, O.; Sengpiel, R.; Wessling, M. Closing the cycle: Phosphorus removal and recovery from diluted effluents using acid resistive membranes. Chem. Eng. J. 2018, 346, 640-648. [CrossRef]

107. Xie, M.; Shon, H.K.; Gray, S.R.; Elimelech, M. Membrane-based processes for wastewater nutrient recovery: Technology, challenges, and future direction. Water Res. 2016, 89, 210-221. [CrossRef]

108. Lee, S.; Boo, C.; Elimelech, M.; Hong, S. Comparison of fouling behavior in forward osmosis (FO) and reverse osmosis (RO). J. Memb. Sci. 2010, 365, 34-39. [CrossRef]

109. Li, Q.; Elimelech, M. Organic fouling and chemical cleaning of nanofiltration membranes: Measurements and mechanisms. Environ. Sci. Technol. 2004, 38, 4683-4693. [CrossRef]

110. Nguyen, N.C.; Chen, S.S.; Yang, H.Y.; Hau, N.T. Application of forward osmosis on dewatering of high nutrient sludge. Bioresour. Technol. 2013, 132, 224-229. [CrossRef]

111. Soler-Cabezas, J.L.; Mendoza-Roca, J.A.; Vincent-Vela, M.C.; Luján-Facundo, M.J.; Pastor-Alcañiz, L. Simultaneous concentration of nutrients from anaerobically digested sludge centrate and pre-treatment of industrial effluents by forward osmosis. Sep. Purif. Technol. 2018, 193, 289-296. [CrossRef]

112. Alkhudhiri, A.; Darwish, N.; Hilal, N. Membrane distillation: A comprehensive review. Desalination 2012, 287, 2-18. [CrossRef]

113. Kim, S.; Lee, D.W.; Cho, J. Application of direct contact membrane distillation process to treat anaerobic digestate. J. Memb. Sci. 2016, 511, 20-28. [CrossRef]

114. Xie, M.; Nghiem, L.D.; Price, W.E.; Elimelech, M. Toward Resource Recovery from Wastewater: Extraction of Phosphorus from Digested Sludge Using a Hybrid Forward Osmosis-Membrane Distillation Process. Environ. Sci. Technol. Lett. 2014, 1, 191-195. [CrossRef]

115. Wang, X.; Wang, Y.; Zhang, X.; Feng, H.; Li, C.; Xu, T. Phosphate recovery from excess sludge by conventional electrodialysis (CED) and electrodialysis with bipolar membranes (EDBM). Ind. Eng. Chem. Res. 2013, 52, 15896-15904. [CrossRef]

116. Wang, X.; Zhang, X.; Wang, Y.; Du, Y.; Feng, H.; Xu, T. Simultaneous recovery of ammonium and phosphorus via the integration of electrodialysis with struvite reactor. J. Memb. Sci. 2015, 490, 65-71. [CrossRef]

117. Barros, L.B.M.; Andrade, L.H.; Drewes, J.E.; Amaral, M.C.S. Investigation of electrodialysis configurations for vinasse desalting and potassium recovery. Sep. Purif. Technol. 2019, 229, 115797. [CrossRef]

118. Holloway, R.W.; Childress, A.E.; Dennett, K.E.; Cath, T.Y. Forward osmosis for concentration of anaerobic digester centrate. Water Res. 2007, 41, 4005-4014. [CrossRef]

119. Thomsen, T.P.; Sárossy, Z.; Ahrenfeldt, J.; Henriksen, U.B.; Frandsen, F.J.; Müller-Stöver, D.S. Changes imposed by pyrolysis, thermal gasification and incineration on composition and phosphorus fertilizer quality of municipal sewage sludge. J. Environ. Manag. 2017, 198, 308-318. [CrossRef]

120. Đurđević, D.; Blecich, P.; Jurić, Ž. Energy recovery from sewage sludge: The case study of Croatia. Energies 2019, $12,1927$. [CrossRef]

121. Facchini, F.; Mummolo, G.; Vitti, M. Scenario Analysis for Selecting Sewage Sludge-to-Energy/Matter Recovery Processes. Energies 2021, 14, 276. [CrossRef]

122. Durdević, D.; Trstenjak, M.; Hulenić, I. Sewage sludge thermal treatment technology selection by utilizing the analytical hierarchy process. Water 2020, 12, 1255. [CrossRef]

123. Tsybina, A.; Wuensch, C. Analysis of sewage sludge thermal treatment methods in the context of circular economy. Detritus 2018, 2, 3-15. [CrossRef]

124. Adam, C.; Kley, G.; Simon, F.G. Thermal treatment of municipal sewage sludge aiming at marketable P-fertilisers. Mater. Trans. 2007, 48, 3056-3061. [CrossRef]

125. Smol, M.; Adam, C.; Kugler, S.A. Thermochemical treatment of Sewage Sludge Ash (SSA)-potential and perspective in Poland. Energies 2020, 13, 5461. [CrossRef]

126. Petzet, S.; Peplinski, B.; Cornel, P. On wet chemical phosphorus recovery from sewage sludge ash by acidic or alkaline leaching and an optimized combination of both. Water Res. 2012, 46, 3769-3780. [CrossRef]

127. Fang, L.; Jiang-shan, L.; Guo, M.Z.; Cheeseman, C.R.; Tsang, D.C.W.; Donatello, S.; Poon, C.S. Phosphorus recovery and leaching of trace elements from incinerated sewage sludge ash (ISSA). Chemosphere 2018, 193, 278-287. [CrossRef] [PubMed]

128. Biswas, B.K.; Inoue, K.; Harada, H.; Ohto, K.; Kawakita, H. Leaching of phosphorus from incinerated sewage sludge ash by means of acid extraction followed by adsorption on orange waste gel. J. Environ. Sci. 2009, 21, 1753-1760. [CrossRef]

129. Baldi, M.; Martinotti, A.; Sorlini, S.; Katsoyiannis, I.A.; Abb, A.; Miino, M.C.; Collivignarelli, M.C. Incinerated Biological Sewage Sludge. Water 2021, 13, 1102. [CrossRef]

130. Guedes, P.; Couto, N.; Ottosen, L.M.; Ribeiro, A.B. Phosphorus recovery from sewage sludge ash through an electrodialytic process. Waste Manag. 2014, 34, 886-892. [CrossRef] [PubMed] 
131. Kirchmann, H.; Börjesson, G.; Kätterer, T.; Cohen, Y. From agricultural use of sewage sludge to nutrient extraction: A soil science outlook. Ambio 2017, 46, 143-154. [CrossRef]

132. Monfet, E.; Aubry, G.; Ramirez, A.A. Nutrient removal and recovery from digestate: A review of the technology. Biofuels 2018, 9 , 247-262. [CrossRef]

133. Khiari, B.; Marias, F.; Zagrouba, F.; Vaxelaire, J. Analytical study of the pyrolysis process in a wastewater treatment pilot station. Desalination 2004, 167, 39-47. [CrossRef]

134. Cantrell, K.B.; Hunt, P.G.; Uchimiya, M.; Novak, J.M.; Ro, K.S. Impact of pyrolysis temperature and manure source on physicochemical characteristics of biochar. Bioresour. Technol. 2012, 107, 419-428. [CrossRef] [PubMed]

135. Cao, Y.; Pawłowski, A. Sewage sludge-to-energy approaches based on anaerobic digestion and pyrolysis: Brief overview and energy efficiency assessment. Renew. Sustain. Energy Rev. 2012, 16, 1657-1665. [CrossRef]

136. Samolada, M.C.; Zabaniotou, A.A. Comparative assessment of municipal sewage sludge incineration, gasification and pyrolysis for a sustainable sludge-to-energy management in Greece. Waste Manag. 2014, 34, 411-420. [CrossRef] [PubMed]

137. Calì, G.; Deiana, P.; Bassano, C.; Meloni, S.; Maggio, E.; Mascia, M.; Pettinau, A. Syngas production, clean-up and wastewater management in a demo-scale fixed-bed updraft biomass gasification unit. Energies 2020, 13, 2594. [CrossRef]

138. Oladejo, J.; Shi, K.; Luo, X.; Yang, G.; Wu, T. A review of sludge-to-energy recovery methods. Energies 2019, 12, 60. [CrossRef]

139. Seggiani, M.; Puccini, M.; Raggio, G.; Vitolo, S. Effect of sewage sludge content on gas quality and solid residues produced by cogasification in an updraft gasifier. Waste Manag. 2012, 32, 1826-1834. [CrossRef]

140. Gorazda, K.; Tarko, B.; Werle, S.; Wzorek, Z. Sewage sludge as a fuel and raw material for phosphorus recovery: Combined process of gasification and P extraction. Waste Manag. 2018, 73, 404-415. [CrossRef] [PubMed]

141. Bridle, T.R.; Pritchard, D. Energy and nutrient recovery from sewage sludge via pyrolysis. Water Sci. Technol. 2004, 50, 169-175. [CrossRef] [PubMed]

142. Vali, N.; Åmand, L.E.; Combres, A.; Richards, T.; Pettersson, A. Pyrolysis of municipal sewage sludge to investigate char and phosphorous yield together with heavy-metal removal-Experimental and by thermodynamic calculations. Energies 2021, 14, 1477. [CrossRef]

143. Atienza-Martínez, M.; Gea, G.; Arauzo, J.; Kersten, S.R.A.; Kootstra, A.M.J. Phosphorus recovery from sewage sludge char ash. Biomass Bioenergy 2014, 65, 42-50. [CrossRef]

144. Gao, N.; Kamran, K.; Quan, C.; Williams, P.T. Thermochemical conversion of sewage sludge: A critical review. Prog. Energy Combust. Sci. 2020, 79, 100843. [CrossRef]

145. Smoliński, A.; Howaniec, N. Co-gasification of coal/sewage sludge blends to hydrogen-rich gas with the application of simulated high temperature reactor excess heat. Int. J. Hydrog. Energy 2016, 41, 8154-8158. [CrossRef]

146. Zhu, J.G.; Yao, Y.; Lu, Q.G.; Gao, M.; Ouyang, Z.Q. Experimental investigation of gasification and incineration characteristics of dried sewage sludge in a circulating fluidized bed. Fuel 2015, 150, 441-447. [CrossRef]

147. Schwitalla, D.; Reinmöller, M.; Forman, C.; Wolfersdorf, C.; Gootz, M.; Bai, J.; Guhl, S.; Neuroth, M.; Meyer, B. Ash and slag properties for co-gasification of sewage sludge and coal: An experimentally validated modeling approach. Fuel Process. Technol. 2018, 175, 1-9. [CrossRef]

148. Kruse, A.; Dahmen, N. Water-A magic solvent for biomass conversion. J. Supercrit. Fluids 2015, 96, 36-45. [CrossRef]

149. Merzari, F.; Langone, M.; Andreottola, G.; Fiori, L. Methane production from process water of sewage sludge hydrothermal carbonization. A review. Valorising sludge through hydrothermal carbonization. Crit. Rev. Environ. Sci. Technol. 2019, 49, 947-988. [CrossRef]

150. Danso-Boateng, E.; Shama, G.; Wheatley, A.D.; Martin, S.J.; Holdich, R.G. Hydrothermal carbonisation of sewage sludge: Effect of process conditions on product characteristics and methane production. Bioresour. Technol. 2015, 177, 318-327. [CrossRef]

151. Escala, M.; Zumbühl, T.; Koller, C.; Junge, R.; Krebs, R. Hydrothermal carbonization as an energy-efficient alternative to established drying technologies for sewage sludge: A feasibility study on a laboratory scale. Energy Fuels 2013, 27, 454-460. [CrossRef]

152. Aragón-Briceño, C.I.; Ross, A.B.; Camargo-Valero, M.A. Mass and energy integration study of hydrothermal carbonization with anaerobic digestion of sewage sludge. Renew. Energy 2021, 167, 473-483. [CrossRef]

153. Zhuang, X.; Huang, Y.; Song, Y.; Zhan, H.; Yin, X.; Wu, C. The transformation pathways of nitrogen in sewage sludge during hydrothermal treatment. Bioresour. Technol. 2017, 245, 463-470. [CrossRef]

154. Aragón-Briceño, C.; Ross, A.B.; Camargo-Valero, M.A. Evaluation and comparison of product yields and bio-methane potential in sewage digestate following hydrothermal treatment. Appl. Energy 2017, 208, 1357-1369. [CrossRef]

155. Saetea, P.; Tippayawong, N. Recovery of Value-Added Products from Hydrothermal Carbonization of Sewage Sludge. ISRN Chem. Eng. 2013, 2013, 268947. [CrossRef]

156. Delzeit, R.; Kellner, U. The impact of plant size and location on profitability of biogas plants in Germany under consideration of processing digestates. Biomass Bioenergy 2013, 52, 43-53. [CrossRef]

157. Saerens, B.; Geerts, S.; Weemaes, M. Phosphorus recovery as struvite from digested sludge-Experience from the full scale. J. Environ. Manag. 2021, 280, 111743. [CrossRef]

158. Guilayn, F.; Rouez, M.; Crest, M.; Patureau, D.; Jimenez, J. Valorization of digestates from urban or centralized biogas plants: A critical review. Rev. Environ. Sci. Biotechnol. 2020, 19, 419-462. [CrossRef] 
159. Huang, H.; Xiao, D.; Pang, R.; Han, C.; Ding, L. Simultaneous removal of nutrients from simulated swine wastewater by adsorption of modified zeolite combined with struvite crystallization. Chem. Eng. J. 2014, 256, 431-438. [CrossRef]

160. Brienza, C.; Sigurnjak, I.; Meier, T.; Michels, E.; Adani, F.; Schoumans, O.; Vaneeckhaute, C.; Meers, E. Techno-economic assessment at full scale of a biogas refinery plant receiving nitrogen rich feedstock and producing renewable energy and biobased fertilisers. J. Clean. Prod. 2021, 308, 127408. [CrossRef]

161. Barampouti, E.M.; Mai, S.; Malamis, D.; Moustakas, K.; Loizidou, M. Exploring technological alternatives of nutrient recovery from digestate as a secondary resource. Renew. Sustain. Energy Rev. 2020, 134, 110379. [CrossRef]

162. Dockhorn, T. About the economy of phosphorus recovery. In International Conference on Nutrient Recovery from Wastewater Streams; IWA Publishing: London, UK, 2009; pp. 145-158.

163. Egle, L.; Rechberger, H.; Krampe, J.; Zessner, M. Phosphorus recovery from municipal wastewater: An integrated comparative technological, environmental and economic assessment of P recovery technologies. Sci. Total Environ. 2016, 571, 522-542. [CrossRef] [PubMed]

164. Luyckx, L.; Geerts, S.; Van Caneghem, J. Closing the phosphorus cycle: Multi-criteria techno-economic optimization of phosphorus extraction from wastewater treatment sludge ash. Sci. Total Environ. 2020, 713, 135543. [CrossRef]

165. Schoumans, O.F.; Rulkens, W.H.; Oenema, O.; Ehlert, P.A.I. Phosphorus recovery from animal manure. Alterra Rep. 2010, 2158, $1-111$. 